\title{
Productive Response of Dairy Cows Fed with Different Levels of Totally Mixed Ration and Pasture
}

\section{Eloy Eduardo Salado ${ }^{1 *}$, Gustavo Bretschneider ${ }^{2}$, Alejandra Cuatrin'1, Adriana María Descalzo ${ }^{3}$, Gerardo Antonio Gagliostro ${ }^{1}$}

\footnotetext{
${ }^{1}$ Area de Investigación en Producción Animal, Instituto Nacional de Tecnología Agropecuaria (INTA), Rafaela, Argentina

${ }^{2}$ Agencia de Extensión Rural Necochea, Instituto Nacional de Tecnología Agropecuaria (INTA), Necochea, Argentina ${ }^{3}$ Instituto de Tecnología de Alimentos(ITA), Instituto Nacional de Tecnología Agropecuaria (INTA), Castelar, Argentina Email: *salado.eloy@inta.gob.ar
}

How to cite this paper: Salado, E.E., Bretschneider, G., Cuatrin, A., Descalzo, A.M. and Gagliostro, G.A. (2018) Productive Response of Dairy Cows Fed with Different Levels of Totally Mixed Ration and Pasture. Agricultural Sciences, 9, 824-851. https://doi.org/10.4236/as.2018.97058

Received: June 24, 2018

Accepted: July 21, 2018

Published: July 24, 2018

Copyright $\odot 2018$ by authors and Scientific Research Publishing Inc. This work is licensed under the Creative Commons Attribution International License (CC BY 4.0).

http://creativecommons.org/licenses/by/4.0/

\begin{abstract}
Forty multiparous Holstein cows in early lactation ( $66 \pm 19$ days) were assigned to one of four treatments that consisted in different ratios of total mixed rations (TMR) and pasture at 100\% TMR (T0), 75:25 (T1) 50:50 (T2) and 25:75 (T3) over 9 weeks in autumn-winter. Measures of rumen parameters and digestion were performed on 4 additional Holstein cows in late lactation (287 days postpartum) fitted with permanent ruminal fistulae and producing $22.6( \pm 5.4) \mathrm{kg}$ milk in a $4 \times 4$ Latin Square design. In T1 to T3 cows were taken to the grazing plot once they finished the pre-planned TMR intake and pasture was offered at 2 times the expected forage DM intake. Milk was analyzed for chemical composition, milk fatty acid (FA) profile and antioxidant compounds. The cows were individually weighed and body condition score (BCS) was determined. After the morning milking, blood samples were taken every 2 weeks and plasma was analyzed for glucose, urea, non-esterified fatty acids (NEFA), insulin, growth hormone (GH) and insulin-like growth factor (IGF-I). Herbage mass in pre grazing strips of pasture averaged $2540 \pm$ $343 \mathrm{~kg} \mathrm{DM} / \mathrm{ha}$. As TMR intake increased, production variables increased linearly excepting milk fat $(3.88 \mathrm{~g} / 100 \mathrm{~g})$ and milk protein $(3.43 \mathrm{~g} / 100 \mathrm{~g})$ contents that were not affected. Milk yield $(\mathrm{kg} / \mathrm{cow} / \mathrm{d})$ resulted maximal in T0 (34.2) and linearly decreased $(\mathrm{p}<0.01)$ with pasture intake averaging 32.1 (T1), 28.4 (T2) and 26.8 (T3) as a higher energy intake and a lower energy cost associated with grazing activity. Milk fat output $(\mathrm{kg} / \mathrm{cow} / \mathrm{d})$ resulted higher in T0 (1.35) and T1 (1.25) compared to T2 (1.10) and T3 (1.04). Milk protein yield $(\mathrm{kg} / \mathrm{cow} / \mathrm{d})$ was also higher in T0 (1.18) and T1 (1.11) compared to T2 (0.96) and T3 (0.92). Total DM (24.09 kg/cow/d) and energy (41.95
\end{abstract}


Mcal NEL/cow/d)) intakes resulted maximal in T0 decreasing as pasture replaced TMR without effects on conversion efficiency ( $1.48 \mathrm{~kg}$ milk/kg DM). Plasma concentration of glucose, insulin and IGF-I were not affected but GH and NEFA increased as pasture replaced TMR in T3. Ruminal pH (5.91) and total or VFA proportions did not differ but $\mathrm{NH}_{3}-\mathrm{N}$ concentration resulted higher in treatments with higher proportion of pasture. Kinetic parameters of DM and NDF digestion from pasture or corn silage were not affected. Milk FA profile and milk antioxidant quality showed unfavorably changes as TMR increased by a decrease in rumenic and linolenic acids and content of antioxidant vitamins, without effect on the atherogenicity index. Results suggested a depressing effect of the pasture on total DM and energy intake probably explained by qualitative deficiencies chemical composition of the forage and/or factors that affect animal behavior that may induce losses in body condition of high yielding dairy cows.

\section{Keywords}

Dairy Cow, Milk Production, Partial Mixed Rations

\section{Introduction}

Milk production systems in Argentina are moving towards more intensified farms to release land for the cultivation of soy (Glycine max) which is considered a more profitable activity than milk production [1]. Accordingly, pasture based systems are being gradually replaced by confined systems in which dairy cows are fed the total mixed rations (TMR) which would allow the expression of the milk production potential of high yielding dairy cows [2]. In the TMR systems feeding costs are higher than in pasture representing more than $50 \%$ of the total costs [3]. Besides their lower production costs, pasture-based systems are characterized by a low environmental impact [4] compared to confined systems but present nutritional limitations that hinder the expression of the production potential of high yielding dairy cows [5].

A feeding alternative is the combination of TMR and grazing which is known as a partially mixed ration (PMR) since pasture is directly grazed by the cows and hence not physically included in the TMR. It combines partial advantages of each system and pasture would not only reduce the amount of TMR included in the total diet and feeding cost but may also improve the dairy herd health [6].

Most of the published studies compared TMR systems vs some combination of pastures plus concentrate or pasture plus TMR. Such comparisons included TMR vs pasture [5] [7], TMR vs pasture plus concentrate [8] [9], TMR vs pasture during the morning or afternoon plus TMR [6] and TMR vs pasture plus concentrate vs a combination of pasture with TMR [10].

The results showed that TMR diets increased total dry matter (DM) intake [5] [6] [8] [10], milk production [5] [6] [8] [9] [10], body weight [5] [9] [10] and 
body condition score [5] [6] [10] [11].

There is still scarce information on the production response obtained in feeding systems combining different proportions of TMR and pasture [12] [13] [14]. In 8 week-long experiments conducted in autumn and spring it was suggested that the autumn pasture can be included in up to $41 \%$ of the total PMR without affecting the productive response compared to a TMR system [12]. In addition no differences in milk production were observed between cows fed 100\% TMR or a TMR:Pasture ratio of 79:21 or 63:37 [13]. According to the authors, this result would be explained by an adequate energy intake in all treatments according to production level [13]. The maximum level of pasture inclusion in the total ration without causing losses in the productive response requires further investigation.

The different TMR and pasture combinations can in turn induce changes in the rumen environment and in DM and fiber digestion in situ [15] or using continuous flow fermenters [2]. Finally, as the level of inclusion of TMR increase, the nutritional healthy value of milk may be affected as a consequence of a decrease in bioactive molecules such as trans-11 $\mathrm{C}_{18: 1}$ or vaccenic acid (VA), 9-cis, 11 -trans $\mathrm{C}_{18: 2}$ or rumenic acid (RA) and $\mathrm{C}_{18: 3 \mathrm{n}-3}$ or $\alpha$-linolenic acid [12] [13] [16] [17]. Likewise, little attention has been paid to the transfer of bioactive compounds such as antioxidant vitamins from diet to milk, although they improve the shelf life of dairy products and have beneficial health properties [18] [19].

The objective of this study was to determine the effect of replacement of an oat pasture (Avena sativa) by TMR on productive response, parameters of metabolic and rumen environment and nutritional healthy value of milk from dairy cows when pasture was comprised between $75 \%$ and $25 \%$ of total DM intake.

\section{Materials and Methods}

\subsection{Cows and Treatments}

The experiment was conducted at the Rafaela Experimental Station from the $\mathrm{Na}$ tional Agricultural Institute of Argentina (INTA, Lat $31^{\circ} 12^{\prime} \mathrm{S}$ Long, $61^{\circ} 30^{\prime} \mathrm{W}$ Alt, $99 \mathrm{~m}$ ) from early autumn (mid April) to winter (mid-July). Forty multiparous Holstein cows ( $2.8 \pm 1.3$ lactations, $550 \pm 63 \mathrm{~kg} \mathrm{BW}, 32.5 \pm 4.0 \mathrm{~kg}$ milk/day) in early lactation (66 \pm 19 days postpartum) were used for the measurements of milk yield and composition, body weight (BW), body condition score (BCS), DM intake and plasma metabolite and hormone concentrations over an experimental period of 9 weeks. Cows were stratified in groups of four according to milk production, parity and days in milk and randomly assigned to one of four treatments (10 cows/treatment). Cows were housed and fed in a dry corral (89 $\mathrm{m}^{2} / \mathrm{cow}$ ) with consolidated floor with lime soil (dry-lot, $48 \mathrm{~m}$ front $\times 74 \mathrm{~m}$ long) divided in 4 pens of equal surface ( 1 for each treatment) with fresh water available ad libitum. During the intake measurement periods, the cows were housed in individual pens for TMR supply. Before the start of the experimental period, cows received the $100 \%$ TMR diet over 3 weeks and production records were 
used as covariate. Treatments consisted in four experimental diets with different TMR:Pasture ratios at 100\% TMR (T0), 75:25 (T1) 50:50 (T2) and 25:75 (T3). Pasture allowance in T1 to T3 was fixed at 2 times [20] the expected forage DM intake according to treatment. On DM basis, the TMR was composed of whole plant corn silage $(35.6 \%)$, a commercial concentrate $(28.7 \%)$, ground corn grain (5.3\%), soybean meal $(6.5 \%)$, roasted soybeans $(5.3 \%)$, cottonseed $(4.9 \%)$ and alfalfa hay (13.7\%).

Measures of rumen parameters and digestion were performed on 4 additional late lactation Holstein cows $(287( \pm 13)$ days in milk) fitted with permanent ruminal fistulae producing $22.6( \pm 5.4) \mathrm{kg}$ milk in a $4 \times 4$ Latin square design. Experimental periods lasted 15 days with 13 days for adaptation and 2 days for data collection. All cows were equipped with neck transponders to record individual and daily milk production (ALPRO version 6.60/DeLaval, Tumba, Sweden). All procedures were consistent with the Guide for the Care and Use of Agricultural Animals in Agricultural Research and Teaching [21].

The amounts of TMR offered in each treatment were weighed daily and refusals were recorded 3 times/week. In T0 the ration was distributed in two daily offers at 6:00 AM and 4:00 PM by halves whereas in T1 they were offered at $80 \%$ in $\mathrm{AM}$ and 20\% in PM. In T2 and T3 the TMR was delivered at 6:00 AM. In treatments that include combinations of TMR and pasture, the cows were taken to the grazing plot once they finished the pre-fixed TMR intake.

\subsection{Samples Collection and Analysis}

Herbage biomass ( $\mathrm{kg} \mathrm{DM} \mathrm{ha}{ }^{-1}$ ) was estimated by cutting samples of forage at the ground level with manual scissors in an area delimited by a metal frame of 0.125 $\mathrm{m}^{2}$ in a total cutting area of $1 \mathrm{~m}^{2}$ in each sampling. The total sample (8 subsamples of $0.125 \mathrm{~m}^{2}$ ) was dried $\left(65^{\circ} \mathrm{C}\right.$ for 48 hours) to determine the DM content. The area of the daily strip was then established according to the pasture allowance defined for each treatment.

Representative samples of feedstuffs, TMR and pasture were taken weekly. Pasture samples were obtained manually in the grazing area simulating the selectivity of the cow (hand-plucking) [22]. All samples were dried in an oven with forced air circulation at $65^{\circ} \mathrm{C}$ until constant weight to determine the DM content and grinded in a Wiley type mill (1 mm mesh). Neutral (NDF) [23] and acid detergent fiber (ADF, [24] procedure 973.18), ether extract (EE, [25] procedure 920.39), acid detergent lignin (ADL, [24], procedure 973.18), total nitrogen (Kjeldhal method, [25] procedure 976.05), crude protein (CP, total nitrogen $\times$ 6.25), ash ([24] procedure 942.05) and in vitro DM digestibility (IVDMD,) by the two-stage fermentation technique were determined [26].

The TMR samples were further sieved and separated by size using the Penn State Particle Separator of two sieves (19 and $8 \mathrm{~mm}$ ) [27] collecting three fractions of long $(>19 \mathrm{~mm})$, medium $(<19 \mathrm{~mm}$ and $>8 \mathrm{~mm})$ and short particles $(<8$ $\mathrm{mm}$ ). The content of NDF $>8 \mathrm{~mm}$ effective fiber (peNDF $>8$ ) was computed as 
the proportion of particles retained in the 19 and $8 \mathrm{~mm}$ sieves of the Penn State Particle Separator, multiplied by the NDF content of the TMR [28].

Milk production was daily and individually measured using the DeLaval ALPRO measuring system (DeLaval International AB, Tumba, Sweden). Milk composition was evaluated from individual samples collected weekly. Two subsamples of milk were taken from each cow in consecutive morning and afternoon milkings using milk meters (DeLaval International AB, Tumba, Sweden) and mixed to make a single individual sample (pool) weighted by the respective production. In each composite sample, milk fat, total protein, lactose, total solids (TS), non-fat solids (NFS) and urea content was determined by infrared spectrophotometry (Milko-Scan ${ }^{\mathrm{TM}}$ Minor, FOSS Electric, Hilleroed, Denmark) according to [29]. Milk casein content was estimated by the expression: $6.38 \times \mathrm{N}$ total- $\mathrm{N}$ non-casein after semi Micro-Kjeldhal digestion. Production of energy corrected milk (ECM) was calculated according to [30].

Individual aliquots of milk (100 ml) were collected biweekly and stored at $-24^{\circ} \mathrm{C}$ for analysis of milk fatty acid (FA) composition and antioxidant compounds. On each sample, lipid was extracted [31] and alkaline methylation of FA was carried out with sodium methoxide (1\%) in anhydrous methanol and then injected into a gas chromatograph (Perkin-Elmer, model Autosystem XL-R 3.5), with PSS injector (Programmed Temperature Vaporizer), flow divider and flame ionization detector (FID). The methyl esters of FA were separated using a capillary column (WCOT fused silica, $200 \mathrm{~m} \times 0.25 \mathrm{~mm}$ i.d., Varian), using $\mathrm{H}_{2}$ as carrier gas. The individual FA were identified by comparing the relative retention times with pure standards (Mix of 37 components AccuStandard, PUFA-2 Animal Source, Supelco, USA) and mix of isomers of methyl ester linoleic acid (Supelco, USA). The analytical results were expressed as percentages of the total FA. The antioxidant vitamins ( $\alpha$-tocopherol, $\gamma$-tocopherol, retinol, $\beta$-carotene and lutein) were analyzed by extraction with saponification in hexane and subsequent separation and quantification using the reverse phase HPLC methodology with detection at $445 \mathrm{~nm}$ for the carotenes and fluorescence at $296-330 \mathrm{~nm}$ for tocopherols [32]. Quantification was based on calibration curves performed with commercial standards of each compound (Sigma-Aldrich, Argentina).

The cows were individually weighed after the morning milking and avoiding access to water every 2 weeks using an electronic scale. At the same time, body condition score (BCS) was determined by the average records of two independent observers using a scale of 5 points $(1=$ excessively skinny and $5=$ excessively fat) with increments of 0.25 [33].

Total DM intake was individually measured during the 4th and 5th weeks of the experimental period on 5 cows of each treatment using $\mathrm{Cr}_{2} \mathrm{O}_{3}$ as an indigestible marker in faeces. During this period, the 20 selected cows were housed in individual pens for the TMR supply and intake was determined by the difference between the quantities of TMR offered and rejected. Pasture intake was estimated from faeces output of each animal and from the pasture IVDMD. In each 
cow, total faeces output was calculated from the amount of $\mathrm{Cr}_{2} \mathrm{O}_{3}$ dosed daily (12 grams per day in two deliveries of 6 grams in gelatin capsules "triple 0 " containing two grams each) and the concentration of $\mathrm{Cr}_{2} \mathrm{O}_{3}$ determined in faeces DM. Capsules containing $\mathrm{Cr}_{2} \mathrm{O}_{3}$ were supplied for 11 consecutive days after each milking by means of a device for bolus administration. During the last 5 days, rectal faeces samples were collected from each cow twice a day after milking. With the faeces of each cow, a composite sample (pool) was formed, representative of the whole period. Each of them was dried to constant weight (stove at $60^{\circ} \mathrm{C}-65^{\circ} \mathrm{C}$ with forced air circulation) and then ground in a Wiley type mill (1 $\mathrm{mm}$ mesh). The determination of the $\mathrm{Cr}_{2} \mathrm{O}_{3}$ concentration in faeces was carried out using the colorimetric method [34]. Faeces production arising from TMR was calculated as the product of the indigestibility of the TMR (1 - IVDMD) by the measured TMR intake. Faeces production linked to pasture intake was determined through the difference between total faeces and TMR faeces output. Pasture intake was estimated from the quotient between the production of faeces associated with pasture and the indigestibility (1 - IVDMD) of the pasture [35]. The equation used was: DM pasture intake in the PMR $=[(\mathrm{g} \mathrm{Cr} / \mathrm{d}) /(\mathrm{g} \mathrm{Cr} / \mathrm{g}$ fecal DM) - TMR DM intake $\times(1$ - TMR IVDMD)]/(1 - pasture IVDMD) [10]. The total DM intake was calculated as the sum of TMR and pasture DM intake.

Metabolizable energy (ME) intake was estimated for each cow with the following equation:

ME intake $\left(\right.$ Mcal day $\left.^{-1}\right)=$ TMR intake $*[$ ME TMR $]+$ Pasture intake $*[$ ME pasture $]$ where: $\mathrm{ME}\left(\mathrm{Mcal} \mathrm{kg} \mathrm{DM}^{-1}\right)=4.4 \mathrm{Mcal}$ gross energy $(\mathrm{GE}) / \mathrm{kg} \mathrm{DM} \times 0.82 \times$ IVDMD.

The net energy for lactation $\left(\mathrm{NE}_{\mathrm{L}}\right)$ intake was calculated as $64 \%$ of $\mathrm{ME}$ [36].

After the morning milking, blood samples were taken every 2 weeks by coccygeal vein puncture. The blood was collected in tubes containing sodium heparin $(5 \mathrm{U} / \mathrm{ml})$ and plasma was obtained by centrifugation $(2000 \times \mathrm{g}$ for $15 \mathrm{~min}$ at $4^{\circ} \mathrm{C}$ ) and stored at $-24^{\circ} \mathrm{C}$ until glucose analysis (Enzymatic blood glucose, Wiener Laboratory, Rosario, Argentina), urea (Uremia, Wiener Laboratory, Rosario, Argentina), non-esterified fatty acids (NEFA, Randox Laboratories Ltd., $\mathrm{UK}$ ), insulin, growth hormone (GH) and somatomedin C or insulin-like growth factor (IGF-I) as previously described [37].

\subsection{Rumen Environment and in Situ NDF Degradability}

The in situ technique [38] using dacron bags $(15.5 \times 7.5 \mathrm{~cm}$ and an average porosity of $52 \mu \mathrm{m}$ ) was used to study the rate and extension of the DM and NDF degradation of the corn silage and the pasture. The day prior to the incubation of the bags, samples of pasture (hand-plucking) and corn silage were collected. To simulate chewing of cows, the pasture samples were cut to a length of approximately $1 \mathrm{~cm}$, while the corn silage samples were processed in a mortar and sieved to homogenize them. At the beginning of the incubation period, two bags 
of each feedstuff (corn silage and pasture) were introduced into the rumen ventral sac of cannulated cows containing 5 grams (DM) of sample at each sampling period. The bags were extracted in duplicate for the different hours of incubation $(0,4,8,12,16,20,24,36$ and $48 \mathrm{hs})$. After each extraction, the bags were frozen $\left(-24^{\circ} \mathrm{C}\right)$ until the end of each period. Subsequently, they were defrosted and washed externally under a stream of cold water to remove the contaminant and soluble material. Then all the bags were washed in washing machines, dried in an oven with forced air circulation $\left(60^{\circ} \mathrm{C}\right.$ for 48 hours) and weighed to determine the DM content of the residue. The NDF content was determined on the residual material of the bags [23]. To describe the kinetics of DM rumen digestion, the model by [39] was used using the solver routine of Excel [40]:

$$
R=S F+I F\left(1-\mathrm{e}^{-(k d * t)}\right)
$$

where: $R(\%)=\mathrm{DM}$ residue (at time after incubation $=t$ ), $S F(\%)=$ soluble fraction, $I F(\%)=$ insoluble fraction, $\mathrm{e}=$ base of natural logarithm, $k d\left(\%\right.$ hour $\left.^{-1}\right)=$ fractional digestion rate and $t$ (hours) $=$ incubation time.

The effective degradability of DM was estimated by the following formula [39]:

$$
E D=S F+I F(k d /(k d+k p))
$$

where: $E D(\%)=$ effective degradability, $S F(\%)=$ soluble fraction, $I F(\%)=$ insoluble fraction, $k d\left(\%\right.$ hour $\left.^{-1}\right)=$ fractional digestion rate and $k p\left(\%\right.$ hour $\left.^{-1}\right)=$ rate of passage, assuming that the latter is $5 \%$ hour $^{-1}$ [41].

To describe the kinetics of cell wall (CW) or NDF rumen digestion, the model proposed by [42] was used using the Excel's solver routine [40]:

$R=D F * \mathrm{e}^{-(k d *(t-L))}+U$, where $R(\%)=$ NDF residue (at time after incubation $=$ $t), D F(\%)=$ degradable fraction, e = base of natural logarithm, $k d=$ fractional digestion rate $\left(\%\right.$ hour $\left.^{-1}\right), L=$ lag time (hours), and $U(\%)=$ undegradable fraction.

The effective degradation of NDF was calculated as: effective degradation $=(D F / 100) *(k d /(k d+k p)) * \mathrm{e}^{-((k p / 100) * L)}$. It was assumed that $k p=5 \%$ hour $^{-1}[41]$.

In the first six sampling times, $200 \mathrm{ml}$ of ruminal liquor from the ventral sac were extracted from each cannulated cow for determination of $\mathrm{pH}$, ammonia-nitrogen $\left(\mathrm{NH}_{3}-\mathrm{N}\right)$ and volatile fatty acid (VFA). On these samples $\mathrm{pH}$ was measured with an ORION model 250 A portable digital $\mathrm{pH}$ meter, immediately after the ruminal liquor was extracted and previously filtered by cloth. One hundred $\mathrm{ml}$ of the filtered liquor was transferred to plastic bottles containing 1 $\mathrm{ml}$ of concentrated sulfuric acid and stored at $-20^{\circ} \mathrm{C}$ until the determinations of $\mathrm{NH}_{3}-\mathrm{N}$ and VFA. The concentration of $\mathrm{NH}_{3}-\mathrm{N}$ was determined by titration with steam distillation, after alkalinization of the samples with sodium hydroxide. For the determination of VFA, the samples were previously purified with orthophosphoric acid (25\%) in $0.5 \mathrm{M}$ sulfuric acid at a rate of $0.5 \mathrm{ml}$ per $2 \mathrm{ml}$ of sample and then centrifuged for $10 \mathrm{~min}$ at $5000 \mathrm{~g}$ [43]. Then, samples were injected 
by a Robokrom ${ }^{\oplus}$ GC self-sampler into a Konik 5000B GC equipped with a flame ionization detector. The VFAs were separated on a Nukol capillary column (30 $\mathrm{m} \times 0.32 \mathrm{~mm}$ i.d. $\times 0.25 \mu \mathrm{m}$ thick, Perkin Elmer-Elite FFAP, Part N9316354). Temperatures of the injector and of the detector were maintained at $250^{\circ} \mathrm{C}$ and that of the column at $156^{\circ} \mathrm{C}$. Hydrogen $\left(\mathrm{H}_{2}\right)$ was used as carrier gas and the column flow was maintained at a rate of $2.4 \mathrm{~mL} / \mathrm{min}$. The Supelco volatile acid mixture (Cat. No. 46975-U) was used for the calibration curves.

\subsection{Statistical Analysis}

Milk production and composition, variation of LW and BC, concentration of metabolites and plasma hormones, milk FA profile and vitamin concentration were analyzed according to a completely randomized design with repeated observations in time adjusted by covariate, using the following model:

$$
Y_{i j k}=\mu+T_{i}+W_{j}+A_{(i) k}+(T \times W)_{i j}+\operatorname{Cov}+E_{i j k}
$$

where: $Y_{i j k}=$ dependent variable, $\mu=$ general average, $T_{i}=$ treatment effect, $W_{j}=$ week effect of sampling, $A_{(i) k}=$ random effect of animal within treatment, $(T \times$ $W)_{i j}=$ effect of treatment interaction $\times$ sampling week, $\mathrm{Cov}=$ covariate and $E_{i j k}$ $=$ residual error.

The environment and ruminal digestion data were analyzed according to a $4 \times$ 4 Latin square design, using the follow

$$
Y_{i j k l m}=\mu+C_{i}+P_{j}+A_{(i) k}+T_{l}+H_{m}+(T \times H)_{l m}+E_{i j k l m}
$$

where: $Y_{i j k l m}=$ dependent variable, $\mu=$ general mean, $S_{i}=$ effect of square, $P_{j}=$ effect of period, $A k_{(i)}=$ random effect of animal within square, $T_{I}=$ effect treatment, $H_{m}=$ effect of the sampling hour, $(T \times H)_{l m}=$ effect of the treatment interaction $\mathrm{x}$ sampling hour and $\mathrm{E}_{i j k l m}=$ residual error.

The consumption data were analyzed by means of a model with a classification criterion (treatment):

$$
Y_{i j}=\mu+T_{i}+E_{i j},
$$

where: $Y_{i j}=$ dependent variable, $\mu=$ general mean, $T_{i}=$ treatment effect and $E_{i j}=$ residual error.

The comparisons between treatment means were made by means of the test for Tukey-Kramer adjusted means $(P=0.05)$. Additionally, linear and/or quadratic effects of TMR levels were tested by orthogonal contrasts. All statistical analyzes were performed using the MIXED procedure of the statistical package of SAS [44].

\section{Results and Discussion}

\subsection{Chemical Composition of Feedstuffs}

Herbage mass in the pregrazing strips of the oat pastures averaged $2540 \pm 343 \mathrm{~kg}$ $\mathrm{DM} \mathrm{ha}{ }^{-1}$. The average chemical composition of the oat pastures and the TMR 
are presented in Table 1.

Pasture DM content was within the critical range (15\% - 18\%) that would affect voluntary intake [45]. Pasture NDF content (43.5\%) resulted higher than values considered as adequate $(34 \%-36 \%)$ to maximize DM intake in dairy cows [46]. The decrease in total DM intake as the proportion of pasture increased in T1, T2 and T3 could in part be explained by pasture DM and NDF contents. Pasture CP content was within the range of $150-250 \mathrm{~g} \mathrm{~kg} \mathrm{DM}^{-1}$ proposed by [47] to obtain high DM digestibility coefficients that resulted high (Table 1).

Composition of the TMR (Table 1) was consistent with that reported in other studies [5] [6] [10] [12] [14]. The average NDF > $8 \mathrm{~mm}$ physically effective content of the TMR (20.1\%) was above the minimum value required $(18.5 \%)$ to prevent the development of subacute ruminal acidosis [28].

\subsection{Milk Production and Composition}

As TMR intake increased, most of the studied variables increased linearly excepting milk fat and protein contents. No quadratic effects were detected for any of the variables analyzed (Table 2). Cows from T0 produced $6.5 \%, 20.4 \%$ and $27.6 \%$ more milk than those of $\mathrm{T} 1, \mathrm{~T} 2$ and $\mathrm{T} 3$, respectively. Cows consuming TMR ad libitum produced $19 \%$ more milk than cows consuming a PMR composed of $70 \%$ of TMR and $30 \%$ of pasture probably explained by differences in energy intake and in the higher energy requirements for maintenance related to the grazing activity equivalent to $3.9 \mathrm{~kg} \mathrm{milk} \mathrm{day}^{-1}$ or $64 \%$ of the difference in milk production between treatments [10]. In the present study, it can be estimated [36] that the energy requirements for maintenance increased $0.51,1.00$ and 1.25 Mcal day ${ }^{-1}$ in the cows of groups T1, T2 and T3, respectively, compared with T0. This would potentially represent $0.79,1.56$ and $1.95 \mathrm{~kg}$ of milk for cows at T1, T2 and T3, respectively. The observed decrease in energy intake (Table 3) plus the additional energy cost associated with grazing activity could explain the difference between treatments in milk production (Table 2). In cows of high genetic merit, $61 \%$ of the difference in milk production between a $100 \%$ pasture diet vs $100 \%$ TMR would be explained by the higher DM and energy intake while grazing activity and excess urea elimination would explain only $24 \%$ and $12 \%$ respectively [5].

Since milk fat and protein contents were not affected, the higher productions observed in $\mathrm{T} 0$ and $\mathrm{T} 1$ respect to $\mathrm{T} 2$ and $\mathrm{T} 3$ were explained by the higher milk output (Table 2). Replacement of TMR by an annual ryegrass pasture in spring did not modify milk solid content but generated a higher fat and milk protein yields when the proportion of TMR was $100 \%$ and $85 \%$ compared to $70 \%$ and $55 \%$ of TMR in the total ration [2].

The treatment $\mathrm{x}$ week interaction was significant $(P<0.01)$ for yield of energy-corrected milk (ECM) (Figure 1). During the first 5 weeks of the experimental period, production of ECM was higher in the two treatments with the highest 
Table 1. Chemical composition of pasture and $\mathrm{TMR}^{1}$.

\begin{tabular}{lcc}
\hline \multicolumn{1}{c}{ Parameters } & Pasture & TMR \\
\hline DM (\%) & $17.8 \pm 1.6$ & $56.1 \pm 3.1$ \\
& & \% of the DM \\
OM & $88.2 \pm 1.1$ & $92.4 \pm 0.6$ \\
IVDDM & $77.6 \pm 5.1$ & $75.4 \pm 3.5$ \\
CP & $20.5 \pm 1.7$ & $16.1 \pm 1.3$ \\
NDF & $43.5 \pm 2.8$ & $36.0 \pm 3.0$ \\
peNDF $>8$ & n.d. ${ }^{2}$ & $20.1 \pm 1.9$ \\
ADF & $20.5 \pm 1.3$ & $18.4 \pm 1.6$ \\
EE & $4.8 \pm 0.4$ & $5.4 \pm 0.4$ \\
\hline
\end{tabular}

${ }^{1}$ Values are expressed as the average \pm standard deviation. ${ }^{2}$ n.d. $=$ not determined. $\mathrm{DM}=$ dry matter; $\mathrm{OM}=$ organic matter; IVDDM = in vitro digestibility of the DM; $\mathrm{CP}=$ crude protein; $\mathrm{NDF}=$ neutral detergent fiber; $\mathrm{ADF}=$ acid detergent fiber; $\mathrm{EE}=$ ether extract; $\mathrm{peNDF}>8=\mathrm{NDF}>8 \mathrm{~mm}$ physically effective, measured as the NDF content of the TMR multiplied by the percentage of particles retained in the 19 and $8 \mathrm{~mm}$ sieves of the Penn State Particle Separator [28].

Table 2. Milk production and composition in dairy cows fed $100 \%$ TMR (T0) or combinations of TMR and pasture at 79:21 (T1), 56:64 (T2) and 30:70 (T3) in the total ration.

\begin{tabular}{|c|c|c|c|c|c|c|c|c|}
\hline \multirow{2}{*}{ Parameter } & \multicolumn{4}{|c|}{ Treatments $^{1}$} & \multirow{2}{*}{ SEM } & \multicolumn{3}{|c|}{$P$-value } \\
\hline & T0 & $\mathrm{T} 1$ & $\mathrm{~T} 2$ & T3 & & $\operatorname{Trat}^{2}$ & Linear ${ }^{3}$ & Quadratic $^{3}$ \\
\hline Milk, kg.d $\mathrm{d}^{-1}$ & $34.2^{\mathrm{a}}$ & $32.1^{\mathrm{b}}$ & $28.4^{\mathrm{c}}$ & $26.8^{\mathrm{d}}$ & 0.30 & 0.01 & 0.01 & 0.10 \\
\hline $\mathrm{ECM}, \mathrm{kg} \cdot \mathrm{d}^{-1}$ & $34.3^{\mathrm{a}}$ & $31.8^{\mathrm{b}}$ & $27.9^{c}$ & $26.6^{\mathrm{d}}$ & 0.33 & 0.01 & 0.01 & 0.10 \\
\hline Fat, $\mathrm{kg} \cdot \mathrm{d}^{-1}$ & $1.35^{\mathrm{a}}$ & $1.25^{\mathrm{a}}$ & $1.10^{\mathrm{b}}$ & $1.04^{\mathrm{b}}$ & 0.03 & 0.01 & 0.01 & 0.62 \\
\hline Fat, \% & 3.92 & 3.90 & 3.91 & 3.80 & 0.07 & 0.62 & 0.27 & 0.50 \\
\hline Protein, $\mathrm{kg} \cdot \mathrm{d}^{-1}$ & $1.18^{\mathrm{a}}$ & $1.11^{\mathrm{a}}$ & $0.96^{\mathrm{b}}$ & $0.92^{\mathrm{b}}$ & 0.02 & 0.01 & 0.01 & 0.55 \\
\hline Protein, \% & 3.44 & 3.48 & 3.39 & 3.43 & 0.05 & 0.69 & 0.67 & 0.99 \\
\hline Lactose, \% & $5.05^{\mathrm{a}}$ & $5.04^{\mathrm{a}}$ & $4.99^{\mathrm{ab}}$ & $4.89^{\mathrm{b}}$ & 0.04 & 0.02 & 0.01 & 0.24 \\
\hline TS, $\%$ & 13.14 & 13.15 & 13.00 & 12.88 & 0.10 & 0.21 & 0.05 & 0.49 \\
\hline SNF, \% & $9.24^{\mathrm{ab}}$ & $9.28^{\mathrm{a}}$ & $9.09^{\mathrm{bc}}$ & $9.07^{c}$ & 0.06 & 0.03 & 0.01 & 0.52 \\
\hline Urea, \% & $0.034^{\mathrm{b}}$ & $0.038^{\mathrm{a}}$ & $0.034^{\mathrm{b}}$ & $0.035^{\mathrm{ab}}$ & 0.001 & $0 ., 01$ & 0.96 & 0.17 \\
\hline Casein, \% & $2.63^{\mathrm{ab}}$ & $2.65^{\mathrm{a}}$ & $2.58^{\mathrm{ab}}$ & $2.57^{\mathrm{b}}$ & 0.02 & 0.02 & 0.01 & 0.44 \\
\hline
\end{tabular}

${ }^{1}$ Values are expressed as least square means (LSMeans) and standard error of LSMeans (SEM). ${ }^{2}$ Treatment effect. ${ }^{3}$ Contrasts. ${ }^{\mathrm{a}, \mathrm{b}, \mathrm{c}, \mathrm{d}}$ LSMeans within row with different letter differ significantly (Tukey-Kramer, $P<$ 0.05). $\mathrm{ECM}=$ milk corrected energy; TS = total solids; SNF = solids non-fat.

Table 3. $\mathrm{DM}$ and $\mathrm{NE}_{\mathrm{L}}$ intake in lactating dairy cows fed 100\% TMR (T0) or combinations of TMR and pasture at 79:21 (T1), 56:64 (T2) and 30:70 (T3) in the total ration.

\begin{tabular}{|c|c|c|c|c|c|c|}
\hline \multirow{2}{*}{ Parameter } & \multicolumn{4}{|c|}{ Treatments $^{1}$} & \multirow{2}{*}{ SEM } & \multirow{2}{*}{$P$-value ${ }^{2}$} \\
\hline & T0 & $\mathrm{T} 1$ & $\mathrm{~T} 2$ & T3 & & \\
\hline $\mathrm{DM}, \mathrm{kg} \cdot \mathrm{d}^{-1}$ & & & & & & \\
\hline
\end{tabular}


Continued

\begin{tabular}{|c|c|c|c|c|c|c|}
\hline Oat pasture & & $4.75^{\mathrm{c}}$ & $9.22^{\mathrm{b}}$ & $13.84^{\mathrm{a}}$ & 0.54 & 0.01 \\
\hline TMR & $24.09^{\mathrm{a}}$ & $17.65^{\mathrm{b}}$ & $11.77^{\mathrm{c}}$ & $5.86^{\mathrm{d}}$ & 0.29 & 0.01 \\
\hline Total & $24.09^{\mathrm{a}}$ & $22.40^{\mathrm{ab}}$ & $21.00^{\mathrm{bc}}$ & $19.70^{c}$ & 0.54 & 0.01 \\
\hline \multicolumn{7}{|l|}{$\mathrm{NE}_{\mathrm{L}}^{3}, \mathrm{Mcal} \mathrm{d}^{-1}$} \\
\hline Oat pasture & & $8.51^{\mathrm{c}}$ & $16.52^{\mathrm{b}}$ & $24.80^{\mathrm{a}}$ & 0.97 & 0.01 \\
\hline TMR & $41.95^{\mathrm{a}}$ & $30.74^{\mathrm{b}}$ & $20.50^{c}$ & $10.20^{\mathrm{d}}$ & 0.51 & 0,01 \\
\hline Total & $41.95^{\mathrm{a}}$ & $39.25^{\mathrm{ab}}$ & $37.02^{\mathrm{bc}}$ & $35.00^{c}$ & 0.96 & 0.01 \\
\hline \multicolumn{7}{|l|}{ Conversion efficiency } \\
\hline Milk, kg DM ${ }^{-1}$ & 1.48 & 1.54 & 1.43 & 1.46 & 0.08 & 0.80 \\
\hline $\mathrm{ECM}, \mathrm{kg} \mathrm{DM}^{-1}$ & 1.42 & 1.50 & 1.46 & 1.43 & 0.07 & 0.84 \\
\hline
\end{tabular}

${ }^{1}$ Values are expressed as least square means (LSMeans) and standard error of LSMeans (SEM). ${ }^{2}$ Treatment effect. ${ }^{3} \mathrm{NE}_{\mathrm{L}}$ values for TMR and oats: 1.74 and $1.79 \mathrm{Mcal} \mathrm{kg} \mathrm{DM}^{-1}$, respectively. ${ }^{\mathrm{a}, \mathrm{b}, \mathrm{L}} \mathrm{LSMeans}$ within row with different letter differ significantly (Tukey-Kramer, $P<0.05$ ).

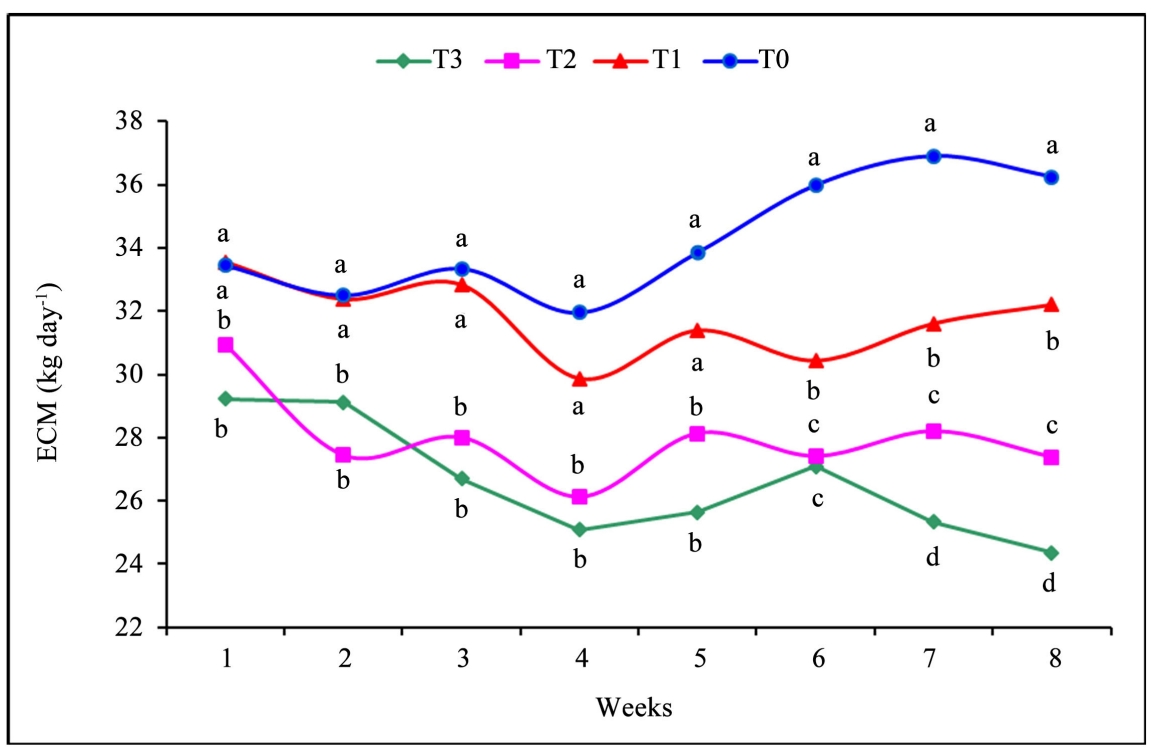

Figure 1. Production of energy-corrected milk (ECM) in dairy cows fed 100\% TMR (T0) or combinations of TMR and pasture at 79:21 (T1), 56:64 (T2) and 30:70 (T3) in the total ration.

proportion of TMR (T0 and T1) while after the 6th experimental week the production registered in TMR-100\% (T0) exceeded the other treatments.

In annual ryegrass spring pastures a linear increase in milk production (from 32.7 to $36.6 \mathrm{~kg} \cdot \mathrm{day}^{-1}$ ), fat corrected milk (from 30.8 to $32.6 \mathrm{~kg} \cdot \mathrm{day}^{-1}$ ) and protein secretion (from 0.93 to $1.04 \mathrm{~kg} \cdot \mathrm{day}^{-1}$ ) was reported as the proportion of the TMR in the ration increased [12]. The increase in milk production would be explained by the higher energy intake and the decrease in energy expenditure associated with grazing activity [12].

Using published data corrected by the study effect as a random factor [48], the 
linear regression analysis performed indicated an average increase of $1.13 \mathrm{~kg} \cdot \mathrm{day}^{-1}$ of milk for every $10 \%$ increase in TMR intake $\left(P<0.01, R^{2}=0.60, \mathrm{n}=36\right.$, Figure 2). At $100 \%$ pasture estimated milk production was $23.74 \mathrm{~kg} \cdot \mathrm{day}^{-1}$ close to the $23.20 \mathrm{~kg} \cdot \mathrm{day}^{-1}$ reported for high quality spring pastures [49].

The prediction model adjusted for yield of ECM indicated an increase of 0.99 $\mathrm{kg} \cdot \mathrm{day}^{-1}$ of milk for every $10 \%$ increase in TMR DM intake (Figure 3). A wide variability of response could also be observed for the 100\% TMR treatments (Figure 2 and Figure 3) that could be linked to genetic merit of cows and/or to the different response of the animal to a given diet (genotype-environment interaction). In this respect, it was showed that under grazing conditions, New

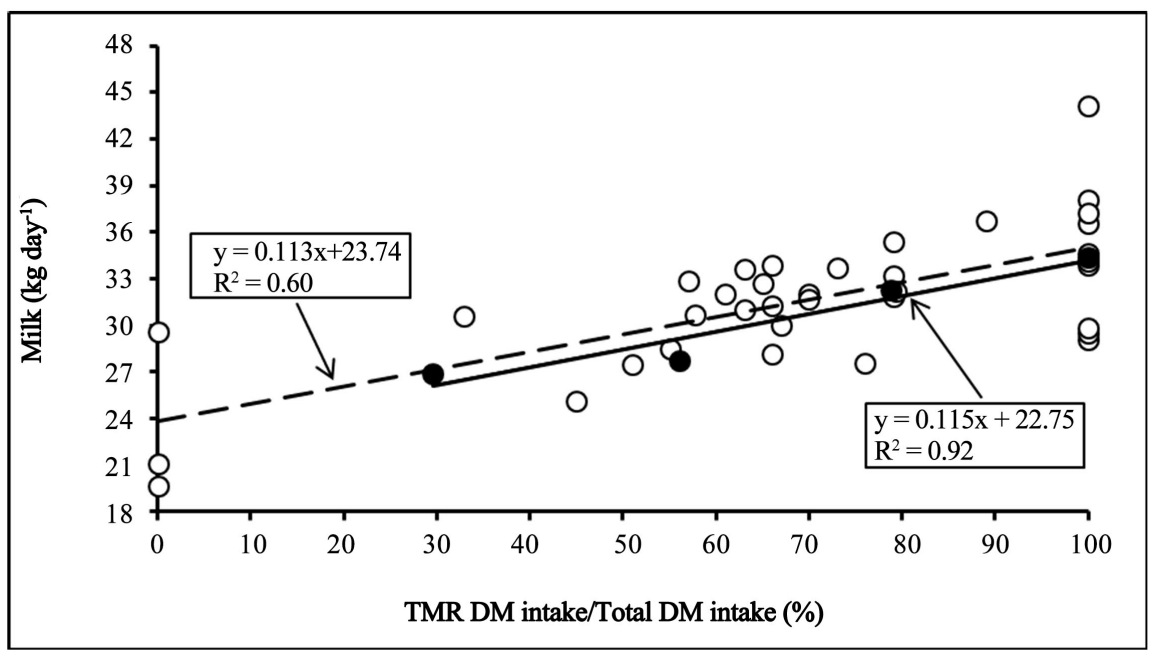

Figure 2. Milk production of dairy cows fed different pasture and TMR proportions. Dotted line and light circles are data from [5] [6] [7] [9] [10] [12] [13] [14] [50] [51] [52]) and continuous line with black circles (data from this study).

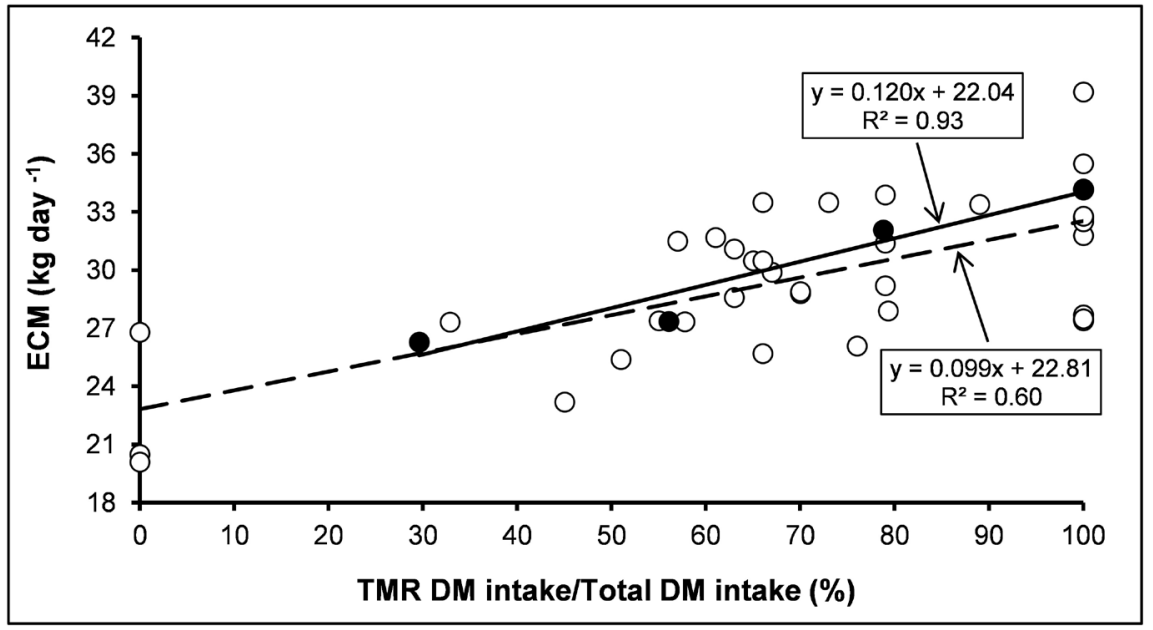

Figure 3. Energy-corrected milk production (ECM) in dairy cows fed with different proportions of pasture and TMR. Dotted line and light circles are data from [5] [6] [7] [9] [10] [12] [13] [14] [50] [51] [52]) and continuous line with black circles (data from this study). 
Zealand Holstein (HN) cows had a higher conversion efficiency (3.4\%) than the American counterpart (HA), whereas under confinement TMR fed conditions the HA cows were more efficient (2.3\%) than HN cows [7].

It should be noted that the results of milk and ECM production observed in the present experiment (solid lines in Figure 2 and Figure 3 ) were adjusted to the models estimated from data from the literature (dotted lines in Figure 2 and Figure 3), being their lines parallel and coincident (both the test effect and the test-response interaction were not significant, $P>0.05)$.

\subsection{Dry Matter and Energy Intake}

According to pre-planned treatments, pasture intake increased when the proportion of TMR decreased but total DM intake resulted lower when pasture replaced TMR (Table 3). Consequently, the actual TMR/Pasture ratios were slightly different from the pre-planned ones resulting in 79:21, 56:44 and 30:70 for $\mathrm{T} 1, \mathrm{~T} 2$ and $\mathrm{T} 3$, respectively. This result is coincident with that reported in a similar trial [12]. The reduction in DM intake in cows consuming PMR compared to $100 \%$ TMR may be explained by a restricted grazing time and a modification of the normal grazing pattern due to confinement schedules imposed to cows which would affect pasture intake [12]. These hypothetical effects were tested comparing one or two grazing sessions when they supplied a PMR composed of 50\% pasture and 50\% TMR [14]. The cows of the group with the longest access to the pasture ( $6 \mathrm{~h}$ post the AM milking and $3 \mathrm{~h}$ post the PM milking) grazed 50 more minutes than those in the group with restricted access $(6 \mathrm{~h}$ post-milking AM) achieving a higher pasture DM intake [14].

The linear regression analysis performed (Figure 4) indicated an increase in total intake of $0.69 \mathrm{~kg} \mathrm{DM} \mathrm{day}^{-1}$ for every $10 \%$ increase in TMR intake evidencing a clear addition effect. The $\alpha$ coefficient (ordered to the origin) indicated a total DM intake of $17.45 \mathrm{~kg} \cdot \mathrm{day}^{-1}$ when pasture was the only feedstuff a value slightly lower (-5\%) than the $18.40 \mathrm{~kg} \mathrm{DM} \mathrm{day}^{-1}$ reported by [53].

Compared to T3, total NEL intake $\left(\mathrm{Mcal} /\right.$ cow $\left.\mathrm{day}^{-1}\right)$ increased when TMR replaced pasture in T2 (9.4), T1 (18.8) and T0 (29.0) without effects on the conversion efficiency (Table 3 ). Since $\mathrm{NE}_{\mathrm{L}}$ intake arising from pasture decreased with increasing levels of TMR $\left(-6.6,-13.0\right.$ and $-19.8 \mathrm{Mcal} / \mathrm{cow} \mathrm{d}^{-1}$ for T2, T1 and T0, respectively) the higher total $\mathrm{NE}_{\mathrm{L}}$ intake was explained by total $\mathrm{DM}$ intake and to $\mathrm{NE}_{\mathrm{L}}$ provided by the TMR. Since cows from T3 apparently mobilized body reserves (Table 4) to sustain milk production, the real differences in conversion efficiency could be partially masked. According to results from Table 3, the regression analyses using published data showed no relationship $(P<0.62)$ between the level of TMR intake and the conversion efficiency (Figure 5).

Taken together, the results obtained suggest a depressing effect of the pasture on total DM and energy intake when it is included as part of the PMR even though the forage offered was as twice as the theoretically expected pasture intake. Qualitative deficiencies in the chemical composition of the forage (DM 
content, NDF excess, energy density) and/or factors that affect animal behavior (access time to the pasture, grazing pattern) could have contributed to explain these results and are predisposing to induce losses in BCS in high yielding dairy cows (Table 4).

Table 4. Variation of body weight (BW), body condition score (BCS) and plasma concentration of metabolites and hormones in lactating dairy cows fed 100\% TMR (T0) or combinations of TMR and pasture at 79:21 (T1), 56:64 (T2) and 30:70 (T3) in the total ration.

\begin{tabular}{|c|c|c|c|c|c|c|c|c|}
\hline \multirow{2}{*}{ Parameter } & \multicolumn{4}{|c|}{ Treatments $^{1}$} & \multirow{2}{*}{ SEM } & \multicolumn{3}{|c|}{ Effects $^{2}, P$-value } \\
\hline & T0 & $\mathrm{T} 1$ & $\mathrm{~T} 2$ & T3 & & Treat & $\mathbf{M}$ & Treat $\times \mathbf{M}$ \\
\hline BW (kg) & $606.2^{\mathrm{a}}$ & $583.4^{\mathrm{b}}$ & $560.8^{c}$ & $543.5^{\mathrm{d}}$ & 4.73 & 0.01 & 0.01 & 0.79 \\
\hline$\Delta \mathrm{BW}(\mathrm{kg})$ & $21.2^{\mathrm{a}}$ & $11.6^{\mathrm{b}}$ & $2.4^{\mathrm{c}}$ & $-6.3^{\mathrm{d}}$ & 2.85 & 0.01 & 0.01 & 0.01 \\
\hline BCS (1 at 5$)$ & $2.45^{\mathrm{a}}$ & $2.42^{\mathrm{a}}$ & $2.21^{\mathrm{b}}$ & $2.00^{\mathrm{c}}$ & 0.06 & 0.01 & 0.16 & 0.63 \\
\hline Glucose $\left(\mathrm{mmol} \cdot \mathrm{l}^{-1}\right)$ & 3.57 & 3.40 & 3.53 & 3.40 & 0.07 & 0.13 & 0.01 & 0.60 \\
\hline Urea $\left(\mathrm{mmol} \cdot \mathrm{l}^{-1}\right)$ & $7.40^{\mathrm{a}}$ & $7.16^{\mathrm{a}}$ & $6.46^{\mathrm{b}}$ & $6.17^{\mathrm{b}}$ & 0.19 & 0.01 & 0.01 & 0.01 \\
\hline \multirow[t]{2}{*}{$\operatorname{NEFA}\left(\mu E q \cdot 1^{-1}\right)$} & $2.23^{\mathrm{b}}$ & $2.23^{\mathrm{b}}$ & $2.30^{\mathrm{b}}$ & $2.44^{\mathrm{a}}$ & 0.04 & 0.01 & 0.01 & 0.01 \\
\hline & (180.6) & (181.5) & (239.4) & $(333.3)$ & & & & \\
\hline \multirow[t]{2}{*}{$\mathrm{GH}\left(\mathrm{ng} \cdot \mathrm{ml}^{-1}\right)$} & $0.06^{\mathrm{b}}$ & $0.13^{\mathrm{b}}$ & $0.20^{\mathrm{ab}}$ & $0.48^{\mathrm{a}}$ & 0.11 & 0.02 & 0.01 & 0.46 \\
\hline & $(1.76)$ & $(2.41)$ & $(2.56)$ & $(4.36)$ & & & & \\
\hline Insulin (ng. ml $\left.{ }^{-1}\right)$ & 0.59 & 0.47 & 0.54 & 0.48 & 0.06 & 0.39 & 0.09 & 0.52 \\
\hline IGF-I (ng.ml $\left.{ }^{-1}\right)$ & 184.2 & 157.9 & 161.6 & 139.4 & 16.9 & 0.30 & 0.04 & 0.53 \\
\hline
\end{tabular}

${ }^{1}$ Values are expressed as least square means (LSMeans) and standard error of LSMeans (SEM). ${ }^{2}$ Treat $=$ treatment, $M=$ sampling, Treat $\times M=$ treatment $\times$ sampling interaction. ${ }^{\text {ab,c,d }}$ LSMeans within row with different letter differ significantly (Tukey-Kramer, $P<0.05$ ). NEFA $=$ non-esterified fatty acids $=\log _{10}$ NEFA; $\mathrm{GH}=$ somatotrophin $=\log _{10} \mathrm{GH}$; IGF-I $=$ somatomedin C. In parentheses, untransformed means of NEFA and GH.

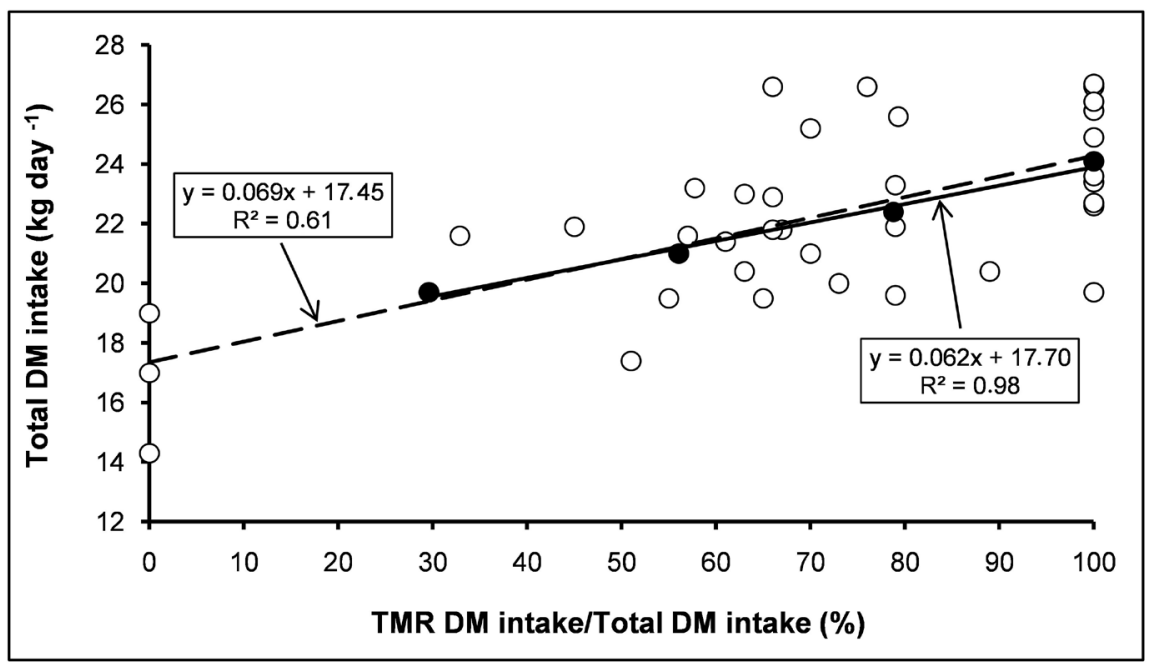

Figure 4. DM intake in dairy cows fed with different proportions of pasture and TMR. Dotted line and light circles are data from [5] [6] [7] [9] [10] [12] [13] [14] [50] [51] [52]) and continuous line with black circles (data from this study). 


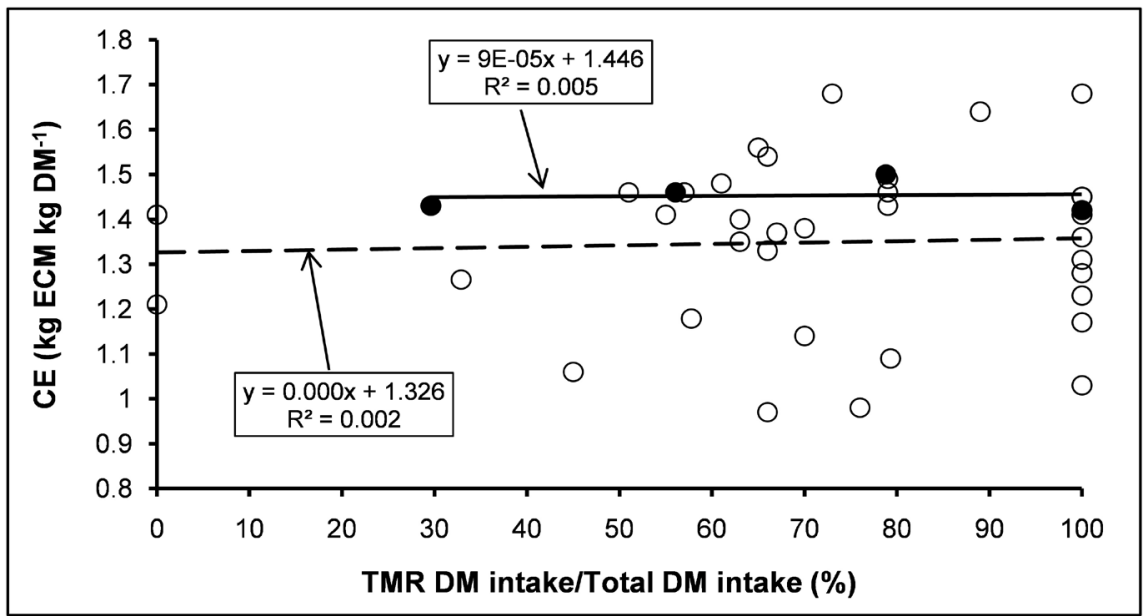

Figure 5. Conversion efficiency (CE) in dairy cows fed with different proportions of pasture and TMR. Dotted line and light circles are data from [5] [6] [7] [9] [10] [12] [13] [14] [50] [51] [52]) and continuous line with black circles (data from this study).

\subsection{Changes in Body Weight, Body Condition Score and Plasma Concentration of Metabolites and Hormones}

As TMR intake increased BW and BCS resulted higher (Table 4) according to the greater estimated $\mathrm{NE}_{\mathrm{L}}$ intake (Table 3 ) and with the reduction of the circulating levels of NEFA, these results also suggest that the animals did not use all the additional energy to increase milk production but that a part was derived to the reconstitution of body reserves. On the other hand, losses of BW recorded in T3 cows $(-6.3 \mathrm{~kg})$ suggest that part of the produced milk was obtained by mobilization of endogenous energy [9]. Several authors reported a negative effect of increasing pasture intake on energy balance of high yielding dairy cows related to the limitations in DM intake which generates losses of BW and BCS [5] [6] [9] [10] [11] [54].

Plasma urea concentration was lower in $\mathrm{T} 2$ and $\mathrm{T} 3$ although $\mathrm{NH}_{3}-\mathrm{N}$ values in the rumen did not differ (Table 5). This result could be linked by a reduced liver capacity to synthesize urea in cows with greater lipomobilization since a lower storage of fat in the liver leads to a better liver function [55]. The in vitro ureogenesis rate decreased linearly following a prolonged exposure of hepatocytes to triglycerides [56]. Plasma urea concentration would be of little metabolic relevance since the range of uremia considered normal in cattle is very wide ranging from 37 to $169 \mathrm{mg} \cdot \mathrm{dl}^{-1}$ [57]. In the present trial, plasma urea values were in the lower limit of the range (Table 4).

Plasma levels of NEFA, glucose, and regulatory hormones (GH and IGF-I) act as dynamic or short-term indicators of energy balance [58] [59]. Cows in negative energy balance show a decrease in plasma glucose, insulin and IGF-I concentrations with higher NEFA and GH levels [60] [61]. Despite differences in calculated $\mathrm{NE}_{\mathrm{L}}$ intake (Table 3 ), glycemia was not affected (Table 4) with values comprised within the normal range ( 2.5 to $4.16 \mathrm{mmol} \cdot \mathrm{l}^{-1}$ ) confirming the high 
homeostatic-hormonal control of blood glucose in cattle [62]. The lack of changes on plasma insulin was consistent with the observed similar plasma glucose levels (Table 4).

Increased pasture intake induced a numerical reduction (25\%) of IGF-I and increased the circulating levels of GH (Table 4) keeping with the decrease in $\mathrm{NE}_{\mathrm{L}}$ intake (Table 3) and the increase in NEFA. Sub nutrition of mid lactation dairy cows doubled plasmatic levels of GH and reduced circulating IGF-I by approximately 50\% [63]. A decrease in number of GH receptors in liver during periods of negative energy balance [64] would contribute to explain the increase in plasma GH concentration and the reduction in liver production of IGF-I observed.

\subsection{Ruminal Environment and Digestion}

Excepting for NH3-N concentration, the treatment $\mathrm{x}$ hour interaction was not significant for most of the ruminal environment parameters studied (Table 5).

Ruminal $\mathrm{pH}$ was not affected by treatments averaging 5.91 (Table 5). Similar ruminal $\mathrm{pH}$ values were reported in cows fed $100 \%$ TMR compared with $70 \%$ TMR plus pasture [15] which represent an intermediate situation to T1 and T2 and pasture (60\%) plus concentrate (40\%). Intake patterns deeply affect ruminal fermentation [65] [66].

Table 5. Ruminal environment in cannulated lactating dairy cows fed 100\% TMR (T0) or combinations of TMR and pasture at 79:21 (T1), 56:64 (T2) and 30:70 (T3) in the total ration.

\begin{tabular}{|c|c|c|c|c|c|c|c|c|}
\hline \multirow{2}{*}{ Parameter } & \multicolumn{4}{|c|}{ Treatments $^{1}$} & \multirow{2}{*}{ SEM } & \multicolumn{3}{|c|}{ Effects $^{2}, P$-value } \\
\hline & T0 & $\mathrm{T} 1$ & $\mathrm{~T} 2$ & T3 & & Treat & Hour & $\begin{array}{c}\text { Treat } \times \\
\text { Hour }\end{array}$ \\
\hline VFA $\left(\mathrm{mmol} \cdot \mathrm{L}^{-1}\right)$ & 140.8 & 154.8 & 169.9 & 151.9 & 8.84 & 0.24 & 0.01 & $0 ., 07$ \\
\hline $\mathrm{Ac}\left(\mathrm{mmol} \cdot \mathrm{L}^{-1}\right)$ & 70.5 & 82.6 & 88.6 & 79.9 & 5.90 & 0.28 & 0.08 & 0.40 \\
\hline $\mathrm{Ac}\left(\mathrm{mol} 100 \mathrm{~mol}^{-1}\right)$ & $53.8^{\mathrm{b}}$ & $57.0^{\mathrm{a}}$ & $56.8^{\mathrm{a}}$ & $58.2^{\mathrm{a}}$ & 0.53 & 0.01 & 0.01 & 0.98 \\
\hline $\operatorname{Pr}\left(\mathrm{mmol} \cdot \mathrm{L}^{-1}\right)$ & 32.9 & 33.2 & 35.3 & 29.6 & 1.6 & 0.21 & 0.01 & 0.13 \\
\hline $\operatorname{Pr}\left(\mathrm{mol} 100 \mathrm{~mol}^{-1}\right)$ & $24.8^{\mathrm{a}}$ & $22.7^{\mathrm{b}}$ & $22.6^{\mathrm{b}}$ & $21.7^{\mathrm{b}}$ & 0.34 & 0.01 & 0.01 & 0.95 \\
\hline Butyrate $\left(\mathrm{mmol} \cdot \mathrm{L}^{-1}\right)$ & 18.5 & 19.4 & 22.4 & 17.3 & 1.06 & 0.06 & 0.02 & 0.53 \\
\hline $\begin{array}{l}\text { Butyrate (mol } 100 \\
\mathrm{~mol}^{-1} \text { ) }\end{array}$ & $14.2^{\mathrm{a}}$ & $13.5^{\mathrm{ab}}$ & $14.4^{\mathrm{a}}$ & $13.1^{\mathrm{b}}$ & 0.36 & 0.04 & 0.01 & 0.65 \\
\hline Ac: $\operatorname{Pr}$ & 2.22 & 2.53 & 2.51 & 2.70 & 0.12 & 0.14 & 0.04 & 0.53 \\
\hline $\mathrm{pH}$ & 6.00 & 5.79 & 5.91 & 5.95 & 0.09 & 0.42 & 0.01 & 0.08 \\
\hline $\mathrm{NH}_{3}-\mathrm{N}\left(\mathrm{mg} \cdot \mathrm{dl}^{-1}\right)$ & 18.81 & 19.59 & 23.52 & 25.08 & 2.76 & 0.38 & 0.01 & 0.01 \\
\hline
\end{tabular}

${ }^{1}$ Values are expressed as least square means (LSMeans) and standard error of LSMeans (SEM). ${ }^{2}$ Treat $=$ treatment, Treat $\times$ Hour $=$ treatment $\times$ hour interaction. ${ }^{\mathrm{a}, \mathrm{b}}$ LSMeans within row with different letter differ significantly (Tukey-Kramer test, $P<0.05$ ). VFA = total volatile fatty acids; $\mathrm{Ac}=$ acetate; $\mathrm{Pr}=$ propionate; $\mathrm{Ac}: \mathrm{Pr}=$ acetate:propionate ratio. 
Ruminal concentration of $\mathrm{NH}_{3}-\mathrm{N}$ was higher in treatments with higher proportion of pasture (T2 and T3) at 8 and 12 hours of sampling and at 16 hour resulted higher in treatments that included pasture (T1, T2 and T3) compared to T0 (Figure 6).

The increase in ruminal $\mathrm{NH}_{3}-\mathrm{N}$ in pasture fed treatments (T1, T2 and T3) occurred after beginning of grazing which is explained by the high ruminal degradability of forage protein. The T0 resulted more stable in terms of daily fluctuations in the $\mathrm{NH}_{3}-\mathrm{N}$ values compared with treatments that included pasture. Indeed, the range of variation observed in T0 was from 13.2 to $23.2 \mathrm{mg} \cdot \mathrm{dl}^{-1}$, while this range was between 8.5 and $32.1,13.6$ and 31.0 and 10.8 and 34.0 $\mathrm{mg} \cdot \mathrm{dl}^{-1}$ in $\mathrm{T} 1, \mathrm{~T} 2$ and $\mathrm{T} 3$ respectively (Figure 6).

Total concentration of VFA did not differ between treatments (Table 5) a result consistent with the similar values of ruminal $\mathrm{pH}$ observed and with results from previous studies [15]. Acetate, propionate and butyrate concentrations and the acetate:propionate ratio were not affected (Table 5) keeping with the absence of treatment effect on milk fat concentration. In the present experiment, the molar proportion of acetate was significantly lower and that of propionate significantly higher in $\mathrm{T} 0$ with respect to $\mathrm{T} 1, \mathrm{~T} 2$ and $\mathrm{T} 3$. The result was consistent with the higher non-structural carbohydrate intake in T0 (9.28 vs $6.70 \mathrm{~kg} \cdot \mathrm{day}^{-1}$, $P<0.01)$.

Kinetics of pasture DM and NDF digestion were not affected (Table 6) keeping with the similar ruminal $\mathrm{pH}$ values observed (Table 5) and suggesting the absence of negative associative effects at ruminal level. A combination of $70 \%$ TMR and 30\% pasture resulted in negative associative effects in the rumen reducing the degradable fraction of pasture DM and NDF compared to a diet comprising $60 \%$ pasture and $40 \%$ concentrate [15].

Values for the parameters of pasture NDF degradation (Table 6) were close to the range reported for dairy cows grazing oat-pastures and supplemented with concentrates $\left(6.5 \mathrm{~kg} \cdot \mathrm{day}^{-1}\right)$ containing different levels and sources of protein [66]. Parameters of DM and NDF degradation from corn silage were also not affected by treatments (Table 7) according to [52].

In the present study, effective fiber content of the TMR (20.1) was above the minimum value required $(18.5 \%)$ to prevent subacute ruminal acidosis and rumen function [28] which would contribute to explain the absence of negative effects on forage digestion.

\subsection{Nutritional Healthy Value of Milk}

Milk FA composition affects its nutritional properties through the balance in the healthy FA (butyric, oleic, polyunsaturated n-3 and CLA) and the potential negative effect of saturated (lauric, myristic and palmitic acids) and trans FA on human health [67]. In this experiment, the proportion of butyric acid $\left(\mathrm{C}_{4: 0}\right)$ in milk fat was not affected (Table 8), a positive result considering its potential beneficial role in human health [67]. 


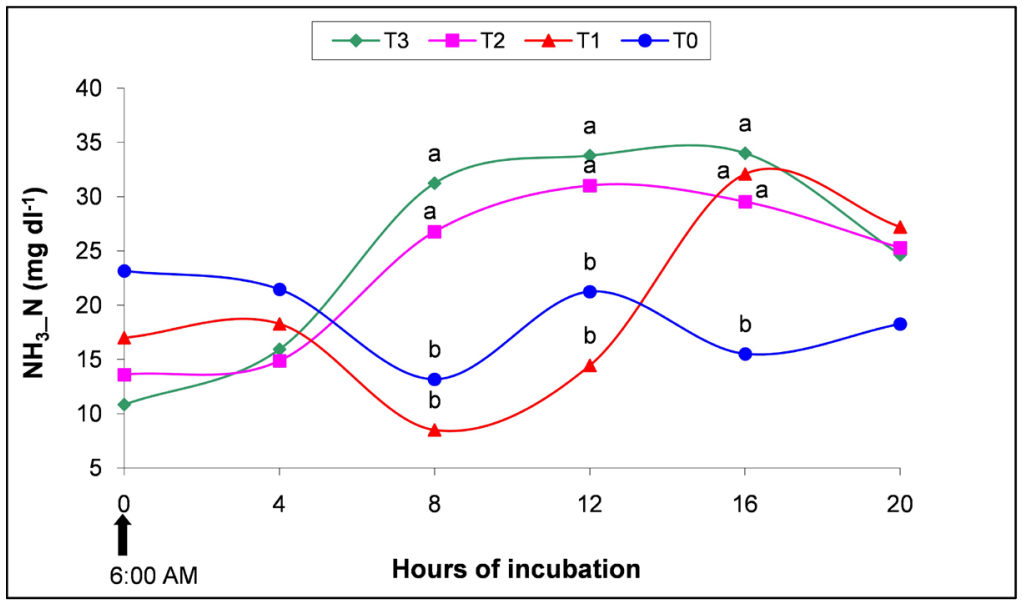

Figure 6. Rumen $\mathrm{NH}_{3}-\mathrm{N}$ concentration in cannulated lactating dairy cows fed 100\% TMR (T0) or combinations of TMR and pasture at 79:21 (T1), 56:64 (T2) and 30:70 (T3) in the total ration.

Table 6. Parameters of pasture DM and NDF degradation in cannulated lactating dairy cows fed 100\% TMR (T0) or combinations of TMR and pasture at 79:21 (T1), 56:64 (T2) and 30:70 (T3) in the total ration.

\begin{tabular}{|c|c|c|c|c|c|c|}
\hline \multirow{2}{*}{ Parameters } & \multicolumn{4}{|c|}{ Treatments $^{1}$} & \multirow{2}{*}{ SEM } & \multirow{2}{*}{$P$-value } \\
\hline & To & $\mathrm{T} 1$ & T2 & T3 & & \\
\hline \multicolumn{7}{|l|}{ DM } \\
\hline Soluble fraction (\%) & 30.80 & 28.28 & 31.31 & 28.11 & 1.90 & 0.55 \\
\hline Insoluble fraction (\%) & 57.78 & 59.66 & 56.96 & 57.24 & 1.39 & 0.56 \\
\hline$k d\left(\% \text { hour }^{-1}\right)^{3}$ & 4.51 & 5.69 & 5.40 & 6.17 & 0.97 & 0.69 \\
\hline Degradable fraction (\%) & 88.58 & 87.94 & 88.26 & 85.35 & 1.67 & 0.54 \\
\hline \multicolumn{7}{|l|}{ Effective degradability $(\%)^{4}$} \\
\hline$k p=5 \%$ hour $^{-1}$ & 58.17 & 58.19 & 59.42 & 58.74 & 1.16 & 0.85 \\
\hline \multicolumn{7}{|l|}{ NDF } \\
\hline Degradable fraction (\%) & 85.18 & 81.44 & 87.99 & 80.03 & 3.27 & 0.38 \\
\hline$k d\left(\% \text { hour }^{-1}\right)^{3}$ & 5.16 & 6.61 & 5.59 & 6.41 & 0.95 & 0.69 \\
\hline Lag time (hours) & 0.90 & 0.84 & 0.00 & 0.67 & 0.67 & 0.77 \\
\hline \multicolumn{7}{|l|}{ Effective degradability ${ }^{4}$} \\
\hline$k p=5 \%$ hour $^{-1}$ & 40.61 & 41.17 & 40.59 & 39.95 & 1.81 & 0.97 \\
\hline
\end{tabular}

${ }^{1}$ Values are expressed as least square means (LSMeans) and standard error of LSMeans (SEM). ${ }^{2}$ Treatment effect. ${ }^{3} k d=$ fractional digestion rate. ${ }^{4}$ Assuming a passage rate $(k p)$ of $5 \%$ hour $^{-1}[41]$.

Table 7. Parameters of corn silage DM and NDF degradation in cannulated lactating dairy cows fed 100\% TMR (T0) or combinations of TMR and pasture at 79:21 (T1), 56:64 (T2) and 30:70 (T3) in the total ration.

\begin{tabular}{ccccccc}
\hline \multirow{3}{*}{ Variable } & \multicolumn{5}{c}{ Treatments $^{1}$} \\
\cline { 2 - 4 } & T0 & T1 & T2 & T3 & $P$-value & \\
& & T0
\end{tabular}




\section{Continued}

\begin{tabular}{|c|c|c|c|c|c|c|}
\hline \multicolumn{7}{|l|}{$\mathrm{DM}$} \\
\hline Soluble fraction (\%) & 22.94 & 22.50 & 24.40 & 29.83 & 2.25 & 0.18 \\
\hline Insoluble fraction (\%) & 55.31 & 56.16 & 51.67 & 57.05 & 10.82 & 0.98 \\
\hline$k d\left(\% \text { hour }^{-1}\right)^{3}$ & 4.32 & 2.45 & 2.84 & 1.81 & 1.50 & 0.70 \\
\hline Degradable fraction (\%) & 78.25 & 78.65 & 76.07 & 86.87 & 12.71 & 0.93 \\
\hline \multicolumn{7}{|l|}{ Effective degradability ${ }^{4}$} \\
\hline$k p=5 \%$ hour $^{-1}$ & 39.86 & 39.38 & 39.68 & 43.16 & 1.11 & 0.15 \\
\hline \multicolumn{7}{|l|}{ NDF } \\
\hline Degradable fraction (\%) & 68.65 & 70.56 & 74.83 & 55.76 & 12.56 & 0.74 \\
\hline$k d\left(\% \text { hour }^{-1}\right)^{3}$ & 2.62 & 1.81 & 1.65 & 4.08 & 0.88 & 0.28 \\
\hline Lag time (hours) & 0.90 & 0.00 & 0.00 & 0.00 & 0.45 & 0.45 \\
\hline \multicolumn{7}{|l|}{ Effective degradability ${ }^{4}$} \\
\hline$k p=5 \%$ hour $^{-1}$ & 19.37 & 17.89 & 17.98 & 19.64 & 1.13 & 0.61 \\
\hline
\end{tabular}

${ }^{1}$ Values are expressed as least square means (LSMeans) and standard error of LSMeans (SEM). ${ }^{2}$ Treatment effect. ${ }^{3} k d=$ fractional digestion rate. ${ }^{4}$ Assuming a passage rate $(k p)$ of $5 \%$ hour ${ }^{-1}$ [41].

Table 8. Concentration of fatty acids (FA) in the milk of lactating dairy cows fed $100 \%$ TMR (T0) or combinations of TMR and pasture at 79:21 (T1), 56:64 (T2) and 30:70 (T3) in the total ration.

\begin{tabular}{|c|c|c|c|c|c|c|c|c|}
\hline \multirow{2}{*}{$\begin{array}{l}\text { Fatty acids }(\mathrm{g} 100 \mathrm{~g} \\
\left.\mathrm{FA}^{-1}\right)\end{array}$} & \multicolumn{4}{|c|}{ Treatments $^{1}$} & \multirow{2}{*}{ SEM } & \multicolumn{3}{|c|}{ Effects $^{2}, P$-value } \\
\hline & T0 & $\mathrm{T} 1$ & $\mathrm{~T} 2$ & T3 & & Treat & $\mathbf{M}$ & Treat $\times M$ \\
\hline $\mathrm{C}_{4: 0}$ & 3.21 & 3.17 & 2.64 & 2.72 & 0.31 & 0.45 & 0.66 & 0.07 \\
\hline$C_{6: 0}$ & 2.07 & 2.21 & 2.06 & 1.96 & 0.14 & 0.66 & 0.63 & 0.50 \\
\hline $\mathrm{C}_{8: 0}$ & 1.26 & 1.32 & 1.34 & 1.21 & 0.05 & 0.39 & 0.68 & 0.95 \\
\hline $\mathrm{C}_{10: 0}$ & $2.80^{\mathrm{ab}}$ & $2.89^{\mathrm{ab}}$ & $3.06^{\mathrm{a}}$ & $2.63^{\mathrm{b}}$ & 0.10 & 0.04 & 0.57 & 0.88 \\
\hline $\mathrm{C}_{10: 1}$ & $0.25^{\mathrm{c}}$ & $0.27^{\mathrm{bc}}$ & $0.32^{\mathrm{a}}$ & $0.30^{\mathrm{ab}}$ & 0.02 & 0.01 & 0.63 & 0.99 \\
\hline $\mathrm{C}_{12: 0}$ & $3.23^{\mathrm{b}}$ & $3.25^{\mathrm{ab}}$ & $3.58^{\mathrm{a}}$ & $3.06^{\mathrm{b}}$ & 0.13 & 0.03 & 0.61 & 0.39 \\
\hline $\mathrm{C}_{12: 1}$ & $0.08^{\mathrm{c}}$ & $0.09^{c}$ & $0.11^{\mathrm{b}}$ & $0.12^{\mathrm{a}}$ & 0.003 & 0.01 & 0.01 & 0.06 \\
\hline $\mathrm{C}_{14: 0}$ & $10.12^{\mathrm{b}}$ & $10.40^{\mathrm{b}}$ & $11.61^{\mathrm{a}}$ & $10.58^{\mathrm{b}}$ & 0.20 & 0.01 & 0.10 & 0.09 \\
\hline $\mathrm{C}_{14: 1}$ & $0.72^{\mathrm{b}}$ & $0.83^{\mathrm{b}}$ & $1.08^{\mathrm{a}}$ & $1.20^{\mathrm{a}}$ & 0.05 & 0.01 & 0.01 & 0.89 \\
\hline $\mathrm{C}_{15: 0}$ & 0.91 & 0.97 & 1.02 & 1.05 & 0.04 & 0.07 & 0.26 & 0.94 \\
\hline $\mathrm{C}_{15: 1}$ & $0.21^{\mathrm{b}}$ & $0.21^{\mathrm{b}}$ & $0.21^{\mathrm{b}}$ & $0.35^{\mathrm{a}}$ & 0.03 & 0.01 & 0.35 & 0.09 \\
\hline $\mathrm{C}_{16: 0}$ & 30.33 & 29.42 & 29.68 & 29.83 & 0.64 & 0.78 & 0.01 & 0.25 \\
\hline$C_{16: 1}$ & $1.37^{\mathrm{bc}}$ & $1.28^{\mathrm{c}}$ & $1.49^{\mathrm{ab}}$ & $1.58^{\mathrm{a}}$ & 0.06 & 0.01 & 0.01 & 0.04 \\
\hline $\mathrm{C}_{17: 0}$ & $0.39^{\mathrm{b}}$ & $0.43^{\mathrm{ab}}$ & $0.50^{\mathrm{a}}$ & $0.47^{\mathrm{ab}}$ & 0.03 & 0.05 & 0.01 & 0.15 \\
\hline $\mathrm{C}_{17: 1}$ & $0.14^{\mathrm{c}}$ & $0.19^{\mathrm{b}}$ & $0.19^{\mathrm{b}}$ & $0.23^{\mathrm{a}}$ & 0.01 & 0.01 & 0.06 & 0.01 \\
\hline $\mathrm{C}_{18: 0}$ & $13.23^{\mathrm{ab}}$ & $14.18^{\mathrm{a}}$ & $11.16^{c}$ & $12.35^{\mathrm{bc}}$ & 0.57 & 0.01 & 0.06 & 0.15 \\
\hline 9-trans $\mathrm{C}_{18: 1}$ & 0.06 & 0.06 & 0.05 & 0.05 & 0.03 & 0.96 & 0.21 & 0.18 \\
\hline
\end{tabular}




\section{Continued}

\begin{tabular}{lcccccccc}
\hline 10-trans $\mathrm{C}_{18: 1}$ & 0.24 & 0.21 & 0.09 & 0.15 & 0.06 & 0.39 & 0.06 & 0.76 \\
11- trans $\mathrm{C}_{18: 1}$ (VA) & $2.68^{\mathrm{b}}$ & $3.16^{\mathrm{a}}$ & $3.23^{\mathrm{a}}$ & $3.15^{\mathrm{a}}$ & 0.10 & 0.01 & 0.01 & 0.36 \\
9-cis $\mathrm{C}_{18: 1}$ & $20.73^{\mathrm{b}}$ & $20.4^{\mathrm{b}}$ & $21.25^{\mathrm{b}}$ & $24.04^{\mathrm{a}}$ & 0.69 & 0.01 & 0.69 & 0.56 \\
11-cis $\mathrm{C}_{18: 1}$ & $0.53^{\mathrm{a}}$ & $0.45^{\mathrm{b}}$ & $0.44^{\mathrm{b}}$ & $0.43^{\mathrm{b}}$ & 0.02 & 0.01 & 0.09 & 0.60 \\
9-cis 12-cis $\mathrm{C}_{18: 2}$ & $3.83^{\mathrm{a}}$ & $3.23^{\mathrm{b}}$ & $2.64^{\mathrm{c}}$ & $2.10^{\mathrm{d}}$ & 0.12 & 0.01 & 0.33 & 0.04 \\
9-trans 12-cis $\mathrm{C}_{18: 2}$ & $0.15^{\mathrm{b}}$ & $0.20^{\mathrm{a}}$ & $0.17^{\mathrm{ab}}$ & $0.18^{\mathrm{ab}}$ & 0.01 & 0.03 & 0.01 & 0.01 \\
C $_{18: 3}$ & $0.40^{\mathrm{d}}$ & $0.51^{\mathrm{c}}$ & $0.61^{\mathrm{b}}$ & $0.68^{\mathrm{a}}$ & 0.02 & 0.01 & 0.26 & 0.56 \\
CLA & & & & & & & & \\
9-cis 11-trans $(\mathrm{RA})$ & $0.72^{\mathrm{d}}$ & $0.84^{\mathrm{c}}$ & $1.11^{\mathrm{b}}$ & $1.23^{\mathrm{a}}$ & 0.04 & 0.01 & 0.11 & 0.97 \\
10-trans 12-cis & $0.08^{\mathrm{b}}$ & $0.11^{\mathrm{a}}$ & $0.10^{\mathrm{ab}}$ & $0.13^{\mathrm{a}}$ & 0.01 & 0.01 & 0.01 & 0.32 \\
9-cis 11-cis & 0.03 & 0.03 & 0.04 & 0.05 & 0.01 & 0.11 & 0.35 & 0.52 \\
9-trans 11-trans & $0.04^{\mathrm{b}}$ & $0.06^{\mathrm{b}}$ & $0.10^{\mathrm{a}}$ & $0.11^{\mathrm{a}}$ & 0.01 & 0.01 & 0.04 & 0.18 \\
RA/VA & $0.27^{\mathrm{c}}$ & $0.27^{\mathrm{c}}$ & $0.34^{\mathrm{b}}$ & $0.39^{\mathrm{a}}$ & 0.01 & 0.01 & 0.73 & 0.42 \\
AI & 2.52 & 2.55 & 2.69 & 2.46 & 0.10 & 0.49 & 0.40 & 0.60 \\
Saturated (SFA ${ }^{4}$ & 59.44 & 60.10 & 59.66 & 58.17 & 0.72 & 0.36 & 0.25 & 0.91 \\
Unsaturated (UFA) & 29.54 & 29.22 & 29.67 & 32.19 & 0.84 & 0.10 & 0.92 & 0.63 \\
Relation SFA:UFA & 2.01 & 2.09 & 2.02 & 1.88 & 0.07 & 0.37 & 0.78 & 0.72 \\
\hline
\end{tabular}

${ }^{1}$ Values are expressed as least square means (LSMeans) and standard error of LSMeans (SEM). ${ }^{2}$ Treat $=$ treatment, $\mathrm{M}=$ sampling, Treat $\times \mathrm{M}=$ treatment $\times$ sampling interaction. ${ }^{3}$ Aterogenicity index: $\left(\mathrm{C}_{12: 0}+4 \times\right.$ $\left.\mathrm{C}_{14: 0}+\mathrm{C}_{16: 0}\right) /\left(\right.$ sum of unsaturated FA). ${ }^{4} \mathrm{SFA}$ : sum of 10:0, 12:0, 14:0, 16:0 and 18:0. ${ }^{5} \mathrm{UFA}$ : sum of 18:1, 18:2, CLA and 18:3. VA = vaccenic acid. RA = rumenic acid. ${ }^{\mathrm{a}, \mathrm{b}, \mathrm{c}, \mathrm{d}}$ LSMeans within row with different letter differ significantly (Tukey-Kramer test, $P<0.05$ ).

Lauric $\left(\mathrm{C}_{12: 0}\right)$ and miristic $\left(\mathrm{C}_{140}\right)$ acids are potentially atherogenic when consumed in excess and resulted slightly higher in T2 with no effect on palmitic $\left(\mathrm{C}_{16: 0}\right)$ acid concentration (Table 8). Concentration of the potentially hypercholesterolemic FA $\left(\mathrm{C}_{12: 0}\right.$ to $\left.\mathrm{C}_{16: 0}\right)$ was lower in cows consuming a $60 \%$ pasture $40 \%$ concentrate diet compared to 70\% TMR 30\% pasture or 100\% TMR ad libitum [68]. In other studies, replacement of TMR by pasture reduced milk concentration of $\mathrm{C}_{16: 0}$ [12] [13].

In our trial, a higher participation of pasture in the diet did not reduce milk content of SFA neither increased that of UFA (Table 8) as observed in other experiments [12] [13] [68] without any effect on the atherogenicity index of milk (Table 8). The lack of effect on milk UFA concentration could be linked to a high ruminal hydrogenation of polyunsaturated FA which in turn may explain the higher VA concentration (Table 8). This FA can be converted to RA in human and animal body tissues and is the main precursor for endogenous synthesis of RA in the mammary gland. Milk content of VA and RA can be increased by pasture intake or by feeding polyunsaturated FA (PUFA) contained in vegetable oils [67]. A special interest is placed on RA for the acquired knowledge about its beneficial effects on human health including the prevention of cancer, 
atherogenesis, lipid peroxidation and obesity [69] [70]. In our study, RA linearly increased as the contribution of pasture in the PMR was raised (Table 8). At maximum pasture intake in T3, milk RA was $10.8 \%, 46.4 \%$ and $70.8 \%$ higher than in T2, T1 and T0 respectively a result that was consistent with previous experiments [12] [13] [17] [68]. Pasture content of $\mathrm{C}_{18: 3}$ increase the production of VA in the rumen and hence RA at the mammary gland [67]. Milk content of RA was linearly increased after intake of $\mathrm{C}_{18: 3}$ contained in high quality pastures [68]. This result may be explained by increased production of VA in the rumen and its subsequent desaturation in the mammary gland, or that RA can effectively be an intermediate in the biohydrogenation of $\mathrm{C}_{18: 3}$ as was suggested by [71].

Besides its healthy (anticancer) properties, VA can be metabolized by humans to bioactive RA [72] at an estimated rate of $20 \%$ [69]. In the present trial, the concentration of VA in milk was significantly lower in T0 compared to treatments that included pasture without significant differences as pasture intake increased from T1 to T3 (Table 8). This result could be explained by a higher delta-9 desaturase activity on VA to produce RA since the RA/VA ratio increased significantly from T1 to T3 (Table 8).

Accordingly to previous studies [12] [13], the concentration of $\mathrm{C}_{18: 3}$ in milk increased with pasture intake (Table 8) due to the high linolenic content in high quality pastures [73] coupled to a high rate of passage. On the other hand, milk content of linoleic acid (cis-9 cis-12 $\mathrm{C}_{18: 2}$ ) increased with participation of TMR in the diet (Table 8) keeping with reports from [12] [13]. A higher linoleic acid intake arising from TMR components (corn grain and silage) may explain this result. Stearic acid $\left(\mathrm{C}_{18: 0}\right)$ increased and oleic acid (cis-9 $\left.\mathrm{C}_{18: 1}\right)$ decreased in treatments with the highest proportion of TMR (T0 and T1) suggesting an increased rumen hydrogenation.

Concentrations of retinol, $\beta$-carotene, lutein and $\alpha$-tocopherol vitamins in milk fat were increased as the proportion of pasture in the total ration was raised (Table 9). Diets rich in concentrate or corn silage would lead to a lower milk content of carotenoids and vitamin E compared to pasture-based diets because fresh forages are rich in these bioactive compounds and the recovery rate of them in milk is directly related to their concentration in the forage [74]. The growing interest in the increase of liposoluble vitamins in milk by natural means in linked to their beneficial effects on human health [19]. Among these compounds, vitamin E ( $\alpha$-tocopherol), the carotenoid precursors of vitamin A ( $\beta$-carotene and lutein) and vitamin $\mathrm{A}$ (retinol) are important for human nutrition and health as natural antioxidants [1]. Lutein can also be used as a biomarker of pasture-feeding since animals cannot synthesize this molecule [75].

When late lactation dairy cows were fed diets with different TMR:pasture ratios (100, 70:30 and 30:70), significant increases in the milk fat content of $\alpha$-tocopherol, retinol and $\beta$-carotene were observed as the proportion of pasture was increased [76]. When diets of $70 \%$ alfalfa pasture $30 \%$ concentrate vs $100 \%$ 
Table 9. Concentration of vitamins in milk fat of lactating dairy cows fed $100 \%$ TMR (T0) or combinations of TMR and pasture at 79:21 (T1), 56:64 (T2) and 30:70 (T3) in the total ration.

\begin{tabular}{|c|c|c|c|c|c|c|c|c|}
\hline \multirow{2}{*}{$\begin{array}{c}\text { Vitamins } \\
\left(\mu \mathrm{g} \mathrm{g} \mathrm{milk} \mathrm{fat}^{-1}\right)\end{array}$} & \multicolumn{4}{|c|}{ Treatments $^{1}$} & \multirow{2}{*}{ SEM } & \multicolumn{3}{|c|}{ Effects $^{2}, P$-value } \\
\hline & T0 & $\mathrm{T} 1$ & $\mathrm{~T} 2$ & $\mathrm{~T} 3$ & & Treat & $\mathbf{M}$ & Treat $\times \mathbf{M}$ \\
\hline Retinol & $2.98^{c}$ & $6.60^{\mathrm{b}}$ & $6.45^{\mathrm{b}}$ & $8.16^{\mathrm{a}}$ & 0.37 & 0.01 & 0.01 & 0.79 \\
\hline$\beta$-carotene & $0.85^{\mathrm{c}}$ & $5.05^{\mathrm{b}}$ & $6.41^{\mathrm{a}}$ & $6.78^{\mathrm{a}}$ & 0.37 & 0.01 & 0.01 & 0.23 \\
\hline Lutein & $0.10^{\mathrm{c}}$ & $0.31^{\mathrm{b}}$ & $0.46^{\mathrm{a}}$ & $0.36^{\mathrm{b}}$ & 0.03 & 0.01 & 0.74 & 0.98 \\
\hline$\alpha$-tocopherol & $18.21^{\mathrm{b}}$ & $18.53^{\mathrm{b}}$ & $21.53^{\mathrm{a}}$ & $23.24^{\mathrm{a}}$ & 0.90 & 0.01 & 0.01 & 0.50 \\
\hline$\gamma$-tocopherol & $4.60^{\mathrm{a}}$ & $2.38^{\mathrm{b}}$ & $1.78^{\mathrm{c}}$ & $1.09^{\mathrm{d}}$ & 0.18 & 0.01 & 0.27 & 0.21 \\
\hline
\end{tabular}

${ }^{1}$ Values are expressed as least square means (LSMeans) and standard error of LSMeans (SEM). ${ }^{2}$ Treat $=$ treatment, $\mathrm{M}=$ sampling, Treat $\times \mathrm{M}=$ treatment $\times$ sampling interaction. ${ }^{\mathrm{a}, \mathrm{b}, \mathrm{c}, \mathrm{d}}$ LSMeans within row with different letter differ significantly (Tukey-Kramer test, $P<0.05$ ).

TMR based on sorghum silage were compared concentrations of $\alpha$-tocopherol, retinol and $\beta$-carotene resulted higher in the pasture based diet [32]. Meanwhile, the concentration of $\gamma$-tocopherol was significantly higher in the TMR probably due to the presence of soybean expeller that is rich in $\gamma$-tocopherol. In our study, the concentration of $\gamma$-tocopherol increased significantly with the inclusion level of TMR in the diet (Table 9).

\section{Conclusion}

The intake of fresh forage in combination with TMR represented a suitable strategy to maintain a high level of milk production in cows selected for a high genetic merit. Milk yield increased linearly with increasing TMR intake in the $30 \%-100 \%$ range explored for cows producing between $27-34 \mathrm{~kg}$ milk/day and was probably explained by a higher energy intake combined with a decrease in energy expenditure associated with grazing activity. The conditions of replacing pasture for TMR should be defined taking into account the depressing effect of pasture on total DM and energy intakes detected when fresh forage is included in high proportion in the partial mixed rations. This effect may amplify the negative energy balance in high yielding dairy cows in early lactation with increased losses of body weight and body condition score and higher circulating levels of non-esterified fatty acids and GH. Some deficiencies in forage quality in addition to animal behavior could exacerbate these effects. Results also suggest that the efficiency of feed to milk conversion may not be altered. Within the wide range of pasture replacement explored no detrimental effects on ruminal environment or FDN degradation were detected suggesting that the positive effects on milk production of TMR intake were not apparently explained at ruminal level. The nutritional and antioxidant quality of milk decreased as the amount of pasture consumed was lower due to lower content of healthy fatty acids like rumenic and linolenic and the fall in the antioxidant vitamins content. It will be interesting to evaluate the effect of replacement of pasture by TMR in continuous long term 
experiments in early lactation cows of high genetic merit in order to quantify actual and residual effects on milk yield as well as the shape of the lactation curve and changes in parameters associated with body lipid mobilization, reproductive hormones and efficiency of milk production.

\section{Acknowledgements}

This work was supported by the National Institute of Agricultural Technology (INTA). This Institute is a decentralized state agency with operational and financial autarchy, under the Ministry of Agroindustry of the Argentine Republic. This publication is part of the requirements to access to the academic degree of Doctor in Agricultural Sciences by the Mar del Plata National University, Argentina.

\section{References}

[1] Descalzo, A.M., Rossetti, L., Páez, R., Grigioni, G., García, P.T., Costabel, L., Negri, L., Antonacci, L., Salado, E., Bretschneider, G., Gagliostro, G., Comerón, E. and Taverna, M.A. (2012) Differential Characteristics of Milk Produced in Grazing Systems and Their Impact on Dairy Products. In: Chaiyabutr, N., Ed., Milk Production-Advanced Genetic Traits, Cellular Mechanism, Animal Management and Health, InTech, Rijeka, 339-368. https://doi.org/10.5772/50760

[2] Vibart, R. (2006) Performance of Lactating Dairy Cows Fed Varying Levels of Total Mixed Ration and Pasture. Ph.D. Thesis, Graduate Faculty of North Carolina State University, Animal Science and Poultry Science, Raleigh, NC.

[3] Dillon, P., Hennessy, T., Shalloo, L., Thorne, F. and Horan, B. (2008) Future Outlook for the Irish Dairy Industry: A Study of International Competitiveness, Influence of International Trade Reform and Requirement for Change: Review. International Journal of Dairy Technology, 61, 16-29. https://doi.org/10.1111/j.1471-0307.2008.00374.x

[4] White, S.L., Sheffield, R.E., Washburn, S.P., King, L.D. and Green Jr., J.T. (2001) Spatial and Time Distribution of Dairy Cattle Excreta in an Intensive Pasture System. Journal of Environmental Quality, 30, 2180-2187. https://doi.org/10.2134/jeq2001.2180

[5] Kolver, E.S. and Muller, L.D. (1998) Performance and Nutrient Intake of High Producing Holstein Cows Consuming Pasture or a Total Mixed Ration. Journal of Dairy Science, 81, 1403-1411. https://doi.org/10.3168/jds.S0022-0302(98)75704-2

[6] Soriano, F.D., Polan, C.E. and Miller, C.N. (2001) Supplementing Pasture to Lactating Holsteins Fed a Total Mixed Ration Diet. Journal of Dairy Science, 84, 2460-2468. https://doi.org/10.3168/jds.S0022-0302(01)74696-6

[7] Kolver, E.S., Roche, J.R., De Veth, M.J., Thorne, P.L. and Napper, A.R. (2002) Total Mixed Rations versus Pasture Diets: Evidence for a Genotype $\times$ Diet Interaction in Dairy Cow Performance. Proceedings of the New Zealand Society of Animal Production, 62, 246-251.

[8] White, S.L., Benson, G.A., Washburn, S.P. and Green Jr., J.T. (2002) Milk Production and Economic Measures in Confinement or Pasture Systems Using Seasonally Calved Holstein and Jersey Cows. Journal of Dairy Science, 85, 95-104. https://doi.org/10.3168/jds.S0022-0302(02)74057-5 
[9] Fontaneli, R.S., Sollenberger, L.E., Littell, R.C. and Staples, C.R. (2005) Performance of Lactating Dairy Cows Managed on Pasture-Based or in Freestall Barn-Feeding Systems. Journal of Dairy Science, 88, 1264-1276. https://doi.org/10.3168/jds.S0022-0302(05)72793-4

[10] Bargo, F., Muller, L.D., Delahoy, J.E. and Cassidy, T.W. (2002) Performance of High Producing Dairy Cows with Three Different Feeding Systems Combining Pasture and Total Mixed Rations. Journal of Dairy Science, 85, 2948-2963. https://doi.org/10.3168/jds.S0022-0302(02)74381-6

[11] Washburn, S.P., White, S.L., Green Jr., J.T. and Benson, G.A. (2002) Reproduction, Mastitis, and Body Condition of Seasonally Calved Holstein and Jersey Cows in Confinement or Pasture Systems. Journal of Dairy Science, 85, 105-111. https://doi.org/10.3168/jds.S0022-0302(02)74058-7

[12] Vibart, R.E., Fellner, V., Burns, J.C., Huntington, G.B. and Green Jr., J.T. (2008) Performance of Lactating Dairy Cows Fed Varying Levels of Total Mixed Ration and Pasture. Journal of Dairy Research, 75, 471-480. https://doi.org/10.1017/S0022029908003361

[13] Morales-Almaráz, E., Soldado, A., González, A., Martínez-Fernández, A., Domínguez-Vara, I., de la Roza-Delgado, B. and Vicente, F. (2010) Improving the Fatty Acid Profile of Dairy Cow Milk by Combining Grazing with Feeding of Total Mixed Ration. Journal of Dairy Research, 77, 225-230. https://doi.org/10.1017/S002202991000004X

[14] Fajardo, M., Mattiauda, D.A., Motta, G., Genro, T.C., Meikle, A., Carriquiry, M. and Chilibroste, P. (2015) Use the Mixed Rations with Different Access Time to Pastureland on Productive Responses of Early Lactation Holstein Cows. Livestock Science, 181, 51-57. https://doi.org/10.1016/j.livsci.2015.09.023

[15] Bargo, F., Muller, L.D., Varga, G.A., Delahoy, J.E. and Cassidy, T.W. (2002) Ruminal Digestion and Fermentation of High-Producing Dairy Cows with Three Different Feeding Systems Combining Pasture and Total Mixed Rations. Journal of Dairy Science, 85, 2964-2973. https://doi.org/10.3168/jds.S0022-0302(02)74382-8

[16] White, S.L., Bertrand, J.A., Wade, M.R., Washburn, S.P., Green Jr., J.T. and Jenkins, T.C. (2001) Comparison of Fatty Acid Content of Milk from Jersey and Holstein Cows Consuming Pasture or a Total Mixed Ration. Journal of Dairy Science, 84, 2295-2301. https://doi.org/10.3168/jds.S0022-0302(01)74676-0

[17] Loor, J.J., Soriano, F.D., Lin, X., Herbein, J.H. and Polan, C.E. (2003) Grazing Allowance after the Morning or Afternoon Milking for Lactating Dairy Cows Fed a Total Mixed Ration (TMR) Enhances trans 11-18:1 and cis 9, trans 11-18:2 (Rumenic Acid) in Milk Fat to Different Extents. Animal Feed Science and Technology, 109, 105-119. https://doi.org/10.1016/S0377-8401(03)00175-5

[18] Nozière, P., Graulet, B., Lucas, A., Martin, B., Grolier, P. and Doreau, M. (2006) Carotenoids for Ruminants: From Forages to Dairy Products. Animal Feed Science and Technology, 131, 418-450. https://doi.org/10.1016/j.anifeedsci.2006.06.018

[19] Calderón, F., Chauveau-Duriot, B., Pradel, P., Martin, B., Graulet, B., Doreau, M. and Nozière, P. (2007) Variations in Carotenoids, Vitamins A and E, and Color in Cow's Plasma and Milk Following a Shift from Hay Diet to Diets Containing Increasing Levels of Carotenoids and Vitamin E. Journal of Dairy Science, 90, 5651-5664. https://doi.org/10.3168/jds.2007-0264

[20] Bargo, F., Muller, L.D., Kolver, E.S. and Delahoy, J.E. (2003) Invited Review: Production and Digestion of Supplemented Dairy Cows on Pasture. Journal of Dairy Science, 86, 1-42. https://doi.org/10.3168/jds.S0022-0302(03)73581-4 
[21] ILAR (2010) Guide for the Care and Use of Laboratory Animals. 7th Edition, National Academy Press, Washington DC.

[22] Meijs, J.A.C., Walters, R.J.K. and Keen, A. (1982) Sward Methods. In: Leaver, J.D., Ed., Herbage Intake Handbook, The British Grassland Society, Grassland Research Institute, Hurley, UK, 11-37.

[23] Komarek, A.R. (1993) An Improved Filtering Technique for the Analysis of Neutral Detergent Fiber and Acid Detergent Fiber Utilizing the Filter Bag Technique. Ankom Tech. Corp., Fairport, Publication No. 101, 1-10.

[24] Association of Official Analytical Chemists (AOAC) (1990) Official Methods of Analysis. 15th Edition, Arlington, VA, USA.

[25] Association of Official Analytical Chemists (AOAC) (1998) Official Methods of Analysis. 16th Edition, Arlington, VA, USA.

[26] Tilley, J.M.A. and Terry, R.A. (1963) A Two-Stage Technique for the in Vitro Digestion of Forage Crops. Journal of the British Grassland Society, 18, 104-111. https://doi.org/10.1111/j.1365-2494.1963.tb00335.x

[27] Lammers, B.P., Buckmaster, D.R. and Heinrichs, A.J. (1996) A Simple Method for the Analysis of Particle Sizes of Forage and Total Mixed Rations. Journal of Dairy Science, 79, 922-928. https://doi.org/10.3168/jds.S0022-0302(96)76442-1

[28] Zebeli, Q., Mansmann, D., Steingass, H. and Ametaj, B.N. (2010) Balancing Diets for Phyphosically Effective Fibre and Ruminally Degradable Starch: A Key to Lower the Risk of Sub-Acute Rumen Acidosis and Improve Productivity of Dairy Cattle. Livestock Science, 127, 1-10. https://doi.org/10.1016/j.livsci.2009.09.003

[29] ISO 9622 IDF 141 (2013) Milk and Liquid Milk Products-Guidelines for the Application of Mid-Infrared Spectrometry.

[30] Tyrrell, H.F. and Reid, J.T. (1965) Prediction of the Energy Value of Cows Milk. Journal of Dairy Science, 48, 1215-1223. https://doi.org/10.3168/jds.S0022-0302(65)88430-2

[31] Luna, P., Juarez, M. and De La Fuente, M.A. (2005) Validation of a Rapid Milk Fat Separation Method to Determine the Fatty Acid Profile by Gas Chromatography. Journal of Dairy Science, 88, 3377-3381. https://doi.org/10.3168/jds.S0022-0302(05)73021-6

[32] Rossetti, L., Langman, L., Grigioni, G.M., Biolatto, A., Sancho, A.M., Comerón, E. and Descalzo, A.M. (2010) Antioxidant Status and Odor Profile in Milk from Silage or Alfalfa-Fed Cows. Australian Journal of Dairy Technology, 65, 3-9.

[33] Wildman, E.E., Jones, G.M., Wagner, P.E., Boman, R.L., Troutt, H.F. and Lesch, T.N. (1982) A Dairy Cow Body Condition Scoring System and Its Relationship to Selected Production Characteristics. Journal of Dairy Science, 65, 495-501. https://doi.org/10.3168/jds.S0022-0302(82)82223-6

[34] Kemura, F.T. and Miller, V.L. (1970) Determinación de Oxido Crómico en Alimento y Heces $\left(\mathrm{HNO}_{3}+\mathrm{HCLO}_{4}\right)$. In: Bateman, J.N., Ed., Métodos Analíticos de Nutrición Animal, Instituto Interamericano de Ciencias Agícolas, 367-369.

[35] Hamilton, B.A., Ashes, J.R. and Carmichael, A.W. (1992) Effect of Formaldehyde-Treated Sunflower Meal on the Milk Production of Grazing Dairy Cows. Australian Journal of Agricultural Research, 43, 379-387. https://doi.org/10.1071/AR9920379

[36] National Research Council (NRC) (2001) Nutrient Requirements of Dairy Cattle. 7th Edition, National Academic Press, Washington DC, USA. 
[37] Salado, E.E., Gagliostro, G.A., Becu-Villalobos, D. and Lacau-Mengido, I. (2004) Partial Replacement of Corn Grain by Hydrogenated Oil in Grazing Dairy Cows in Early Lactation. Journal of Dairy Science, 87, 1265-1278. https://doi.org/10.3168/jds.S0022-0302(04)73277-4

[38] Mehrez, A.Z. and Ørskov, E.R. (1977) A Study of the Artificial Fibre Bag Technique for Determining the Digestibility of Feeds in the Rumen. The Journal of Agricultural Science, 88, 645-650. https://doi.org/10.1017/S0021859600037321

[39] Ørskov, E.R. and McDonald, I. (1979) The Estimation of Protein Degradability in the Rumen from Incubation Measurements Weighted According to Rate of Passage. The Journal of Agricultural Science, 92, 499-503.

[40] Fernández, H.H. (2004) Un Procedimiento Simple para Estimar Parámetros de Funciones Utiles en Producción Animal Usando Solver de Excel. Revista Argentina de Producción Animal, 24, 75-85.

[41] Van Vuuren, A.M., Krol-Kramer, F., Van der Lee, R.A. and Corbijn, H. (1992) Protein Digestion and Amino Acids in Dairy Cows Fed Fresh Lolium perenne with Different Nitrogen Contents. Journal of Dairy Science, 75, 2215-2225. https://doi.org/10.3168/jds.S0022-0302(92)77982-X

[42] Mertens, D.R. and Loften, J.R. (1980) The Effect of Starch on Forage Fiber Digestion Kinetics in Vitro. Journal of Dairy Science, 63, 1437-1446. https://doi.org/10.3168/jds.S0022-0302(80)83101-8

[43] Friggens, N.C., Oldham, J.D., Dewhurst, R.J. and Horgan, G. (1998) Proportions of Volatile Fatty Acids in Relation to the Chemical Composition of Feeds Based on Grass Silage. Journal of Dairy Science, 81, 1331-1344. https://doi.org/10.3168/jds.S0022-0302(98)75696-6

[44] SAS Institute Inc. (2010) SAS/STAT ${ }^{\circ}$ User's Guide. SAS Institute, Cary, NC, USA.

[45] Verité, R. and Journet, M. (1970) Influence de la Teneur en Eau et de la Deshydratation de l'Herbe sur sa Valeur Alimentaire pour les Vaches Laitières. Annales de Zootechnie, 10, 269-277.

[46] Mertens, D.R. (1994) Regulation of Forage Intake. In: Fahey Jr., E. and Madison, G.G., Eds., Forage Quality, Evaluation and Utilization, American Society of Agronomy, Inc., Crop Science Society of America, Soil Science Society of America Inc., Madison, WI, USA, 59-114.

[47] Minson, D.J. (1990) Forage in Ruminant Nutrition. Academic Press, Inc., Queensland, Australia.

[48] St-Pierre, N.R. (2001) Integrating Quantitative Findings from Multiple Studies Using Mixed Model Methodology. Journal of Dairy Science, 84, 741-755. https://doi.org/10.3168/jds.S0022-0302(01)74530-4

[49] Delaby, L. and Peyraud, J.L. (1997) Influence of Concentrate Supplementation Strategy on Grazing Dairy Cow's Performance. Proceedings of the XVIII International Grassland Congress, Winnipeg, Canada, 137-138.

[50] O’Neill, B.F., Deighton, M.H., O’Loughlin, B.M., Mulligan, F.J., Boland, T.M., O’Donovan, M. and Lewis, E. (2011) Effects of a Perennial Ryegrass Diet or Total Mixed Ration Diet Offered to Spring-Calving Holstein-Friesian Dairy Cows on Methane Emissions, Dry Matter Intake, and Milk Production. Journal of Dairy Science, 94, 1941-1951. https://doi.org/10.3168/jds.2010-3361

[51] Auldist, M.J., Marett, L.C., Greenwood, J.S., Wright, M.M., Hannah, M., Jacobs, J.L. and Wales, W.J. (2014) Replacing Wheat with Canola Meal in a Partial Mixed Ration Increases the Milk Production of Cows Grazing at a Restricted Pasture Allow- 
ance in Spring. Animal Production Science, 54, 869-878.

[52] Quilaguy, G.A. (2015) Respuesta Productiva de Vacas Lecheras Alimentadas con Diferentes Niveles de Ración Totalmente Mezclada y Pastura. Programa de Posgrado en Ciencias Agrarias. Curso de Posgrado en Producción Animal. Facultad de Ciencias Agrarias, Universidad Nacional de Mar del Plata. Estación Experimental Agropecuaria de Balcarce, INTA.

[53] Delagarde, R., Prache, S., D’Hour, P. and Petit, M. (2001) Ingestion de l'Herbe par les Ruminants au Pâturage. Fourrages, 166, 189-212.

[54] Tucker, W.B., Rude, B.J. and Wittayakun, S. (2001) Performance and Economics of Dairy Cows Fed a Corn Silage-Based Total Mixed Ration or Grazing Annual Ryegrass during Mid to Late Lactation. The Professional Animal Scientist, 17, 195-201. https://doi.org/10.15232/S1080-7446(15)31622-3

[55] Duffield, T.F., Rabbie, A.R. and Lean, I.J. (2008) A Meta-Analysis of the Impact of Monensin in Lactating Dairy Cattle. Part 1. Metabolic Effects. Journal of Dairy Science, 91, 1334-1346. https://doi.org/10.3168/jds.2007-0607

[56] Strang, B., Bertics, S., Grummer, R. and Armentano, L. (1998) Effect of Long-Chain Fatty Acids on Triglyceride Accumulation, Gluconeogenesis, and Ureagenesis in Bovine Hepatocytes. Journal of Dairy Science, 81, 728-739. https://doi.org/10.3168/jds.S0022-0302(98)75629-2

[57] Radostits, O.M., Gay, C.C., Hinchcliff, K.W. and Constable, P.D. (2006) Veterinary Medicine. 10th Edition, Saunders Elsevier, Philadelphia, 2162-2165.

[58] Cissé, M., Chilliard, Y., Coxam, V., Davicco, M.J. and Remond, B. (1991) Slow Release Somatotropin in Dairy Heifers and Cows Fed Two Levels of Energy Concentrate. 2. Plasma Hormones and Metabolites. Journal of Dairy Science, 74, 1382-1394. https://doi.org/10.3168/jds.S0022-0302(91)78293-3

[59] Chilliard, Y., Bocquier, F. and Doreau, M. (1998) Digestive and Metabolic Adaptations of Ruminants to Undernutrition and Consequences on Reproduction. Reproduction Nutrition Development, 38, 131-152. https://doi.org/10.1051/rnd:19980201

[60] Grummer, R.R. (1995) Impact of Changes in Organic Nutrient Metabolism on Feeding the Transition Dairy Cow. Journal of Animal Science, 73, 2820-2833.

[61] Van Knegsel, A.T.M., Van der Brand, H., Graat, E.A.M., Dijkstra, J., Jorritsma, R., Decuypere, E., Tamminga, S. and Kemp, B. (2007) Dietary Energy Source in Dairy Cows in Early Lactation: Metabolites and Metabolic Hormones. Journal of Dairy Science, 90, 1477-1485. https://doi.org/10.3168/jds.S0022-0302(07)71633-8

[62] Noro, M., Vargas, V., Pulido, R.G. and Wittwer, F. (2006) Efecto del Tipo de Concentrado Sobre Indicadores Sanguíneos del Metabolismo de Energía y de Proteínas en Vacas Lecheras en Pastoreo Primaveral. Archivos de Medicina Veterinaria, 38, 227-232. https://doi.org/10.4067/S0301-732X2006000300005

[63] McGuire, M.A., Bauman, D.E., Dwyer, D.A. and Cohick, W.S. (1995) Nutritional Modulation of the Somatotropin/Insulin-Like Growth Factor System: Response to Feed Deprivation in Lactating Cows. Journal of Nutrition, 125, 493-502.

[64] Breier, B.H., Gluckman, P.D. and Bass, J.J. (1988) The Somatotrophic Axis in Young Steers: Influence of Nutritional Status and Oestradiol-17 $\beta$ on Hepatic Highand Low-Affinity Somatotrophic Binding Sites. Journal of Endocrinology, 116, 169-177. https://doi.org/10.1677/joe.0.1160169

[65] Van Vuuren, A.M., Van der Koelen, J. and Vroons-de Bruin, J. (1986) Influence of the Level and Composition of Concentrate Supplements on Rumen Fermentation Patterns of Grazing Dairy Cows. Netherlands Journal of Agricultural Science, 34, 
457-467.

[66] Bargo, F., Rearte, D.H., Santini, F.J. and Muller, L.D. (2001) Ruminal Digestion by Dairy Cows Grazing Winter Oats Pasture Supplemented with Different Levels and Sources of Protein. Journal of Dairy Science, 84, 2260-2272. https://doi.org/10.3168/jds.S0022-0302(01)74673-5

[67] Chilliard, Y., Ferlay, A., Mansbridge, R.M. and Doreau, M. (2000) Ruminant Milk Fat Plasticity: Nutritional Control of Saturated, Polyunsaturated, Trans and Conjugated Fatty Acids. Annales de Zootechnie, 49, 181-205. https://doi.org/10.1051/animres:2000117

[68] Bargo, F., Delahoy, J.E., Schroeder, G.F., Baumgard, L.H. and Muller, L.D. (2006) Supplementing Total Mixed Rations with Pasture Increase the Content of Conjugated Linoleic Acid in Milk. Animal Feed Science and Technology, 131, 226-240. https://doi.org/10.1016/j.anifeedsci.2006.04.017

[69] Stanton, C., Murphy, J., McGrath, E. and Devery, R. (2003) Animal Feeding Strategies for Conjugates Linoleic Acid Enrichment of Milk. In: Sebedio, J.L., Christie, W.W. and Adloff, R., Eds., Advances in Conjugated Linoleic Acid in Food, AOCS Press, Champaign, IL, 123-145.

[70] Parodi, P.W. (1999) Conjugated Linoleic Acid and Other Anticarcinogenic Agents of Bovine Milk Fat. Journal of Dairy Science, 82, 1339-1349. https://doi.org/10.3168/jds.S0022-0302(99)75358-0

[71] Kay, J.K., Roche, J.R., Kolver, E.S., Thomson, N.A. and Baumgard, L.H. (2005) A Comparision between Feeding Systems (Pasture and TMR) and the Effect of Vitamin E Supplementation on Plasma and Fatty Acid Profiles in Dairy Cows. Journal of Dairy Research, 72, 322-332. https://doi.org/10.1017/S0022029905000944

[72] Gagliostro, G.A. (2004) Control Nutricional del Contenido de Acido Linoleico Conjugado (CLA) en Leche y su Presencia en Alimentos Naturales Funcionales. 1. Efectos Sobre la Salud Humana. Revista Argentina de Producción Animal, 24, 113-136.

[73] Elgersma, A. and Wever, A.C. (2005) Grazing Fresh Grass at a High Herbage Allowance Results in Milk with a Higher CLA Concentration than a Maize Silage Diet. Modern Aspects of Fats and Oils. Abstracts of the 26 th World Congress and Exhibition of the International Society for Fat Research (ISF), Prague, Czech Republic, 25-28 September 2005, 61.

[74] Martin, B., Fedele, V., Ferlay, A., Grolier, P., Rock, E., Gruffat, D. and Chilliard, Y. (2004) Effects of Grass-Based Diets on the Content of Micronutrients and Fatty Acids in Bovine and Caprine Dairy Products. In: Lüscher, A., Jeangros, B., Kessler, W., Huguenin, O., Lobsiger, M., Millar, N. and Suter, D., Eds., Land Use Systems in Grassland Dominated Regions, Vol. 9, Vdf, Zürich, 876-886.

[75] Prache, S., Cornu, A., Berdagué, J.L. and Priolo, A. (2005) Traceability of Animal Feeding Diet in the Meat and Milk of Small Ruminants. Small Ruminant Research, 59, 157-168. https://doi.org/10.1016/j.smallrumres.2005.05.004

[76] La Terra, S., Marino, V.M., Manenti, M., Licitra, G. and Carpino, S. (2010) Increasing Pasture Intakes Enhances Polyunsaturated Fatty Acids and Lipophilic Antioxidants in Plasma and Milk of Dairy Cows Fed Total Mix Ration. Dairy Science \& Technology, 90, 687-698. https://doi.org/10.1051/dst/2010100 